\title{
Chapter 1 \\ The High Mountain Conservation in a Changing World
}

\author{
Jordi Catalan, Josep M. Ninot and M. Mercè Aniz
}

\begin{abstract}
The high mountains have retained a noticeable degree of wilderness even in the most populated regions of the planet. This is the reason why many nature reserves have been established in these landscapes. Currently, climate change and long-range transport of contaminants are affecting those protected areas, and thus conservation priorities may be challenged by these new pressures. In fact, many high mountains hold a legacy of on-site past human activities (e.g., pasturing, forestry, mining), which in some areas may partially persist, even increase, whereas in others are substituted by new uses (e.g., tourism, mountain sport). Therefore, high mountain nature reserves face a challenging future. The conservation goals have to be revised. Former alternative paradigms respectively based on the preservation of wilderness or a traditional cultural landscape will be insufficient. Indeed, global change provides new goals for the high mountain conservation areas as suitable places where to study the nature's response in the absence of, or combined with, other local pressures. Different branches of sciences may contribute to inform about the changes; however, conservation is ultimately a societal endeavour and thus their goals must be linked to the social demand for a fair society in a sustainable planet. As an added-value to this task, the high mountains hold a large amount of symbolism.
\end{abstract}

Keywords Nature reserves - Climate change - Landscape shifts - Alpine biota • Long-range atmospheric contamination $\cdot$ Land use change $\cdot$ Mountain resources

\footnotetext{
J. Catalan (ه)

CREAF - CSIC, Campus UAB, Edifici C, 08193 Cerdanyola del Vallès, Catalonia, Spain e-mail: j.catalan@creaf.uab.cat

\section{J.M. Ninot}

Departament de Biologia Evolutiva, Ecologia i Ciències Ambientals, Institut de Recerca de la Biodiversitat (IRBio), Universitat de Barcelona, Diagonal 643, 08028 Barcelona, Catalonia, Spain

M.M. Aniz

Parc Nacional d'Aigüestortes i Estany de Sant Maurici,

Ca de Simamet, C. de les Graieres 2, 25558 Boí, Catalonia, Spain
}

(C) The Author(s) 2017

J. Catalan et al. (eds.), High Mountain Conservation in a Changing World,

Advances in Global Change Research 62, DOI 10.1007/978-3-319-55982-7_1 


\subsection{Introduction}

\subsubsection{Conservation in a Changing World}

The increasing recognition of global change may place traditional conservation goals in a deadlock. Mountains have been flagship lands of conservation around the world. Although plenty of natural resources, mountains have generally been less amenable to the settling of large human populations. Their relative societal marginal role, together with their intrinsic natural values, has facilitated the creation of nature reserves with the general goal of preserving species and natural landscapes. Although climatic variability has long been recognized, the declaration of nature reserves was based on the assumption that things would not change significantly for many generations and thus the preserved lands will remain pristine or recover a state close to that if they had been highly modified by humans. Obviously, there were differences among continents. In the less populated regions, preserving wilderness played a central role (e.g., western North America) whereas in countries with a long tradition of mountain use the conservation goal often included human activities that were considered traditional in those landscapes (Radkau 2008; Beniston and Stoffel 2014). Yet the central conservation goals may have differed among countries or shifted with time since nature reserves started to be formulated in the late 19th century, the alternative views were not challenged by anything that could not be apparently managed at a local, regional or national scale.

Now the situation has drastically changed. National Parks and other nature reserves will have to review their foundational goals. Beyond managing their internal problems and the pressures from their immediate natural and societal surroundings, they will have to deal with atmospheric drivers (Fig. 1.1) that may shift their natural systems to situations completely unexpected in the recent past (DeFries et al. 2012). These changing conditions will overlap with parallel changes in the local and regional socio-economic context that will also be reacting to the new situation (Pearson 2016). The larger the expected problem, the sooner the reaction should be planned (Margalef 1976). Given the global change scenarios, it is opportune to analyze the role of high-mountain nature reserves in a context of persistent change, evaluate whether there are non-sustainable goals and discuss alternative aims more in accordance to the new situation.

\subsubsection{Vulnerability, Exposure, and Sensitivity}

The eventual vulnerability of an ecosystem to some perturbation depends on both the degree of exposure, and the sensitivity to it (Lloret 2017). High mountains are particularly exposed to some of the atmospheric global change components (Steffen et al. 2015): high mountains are prompt to shifts in climatic extremes (Rangwala et al. 2012); the atmosphere is thinner, so UV radiation is higher, particularly in the 


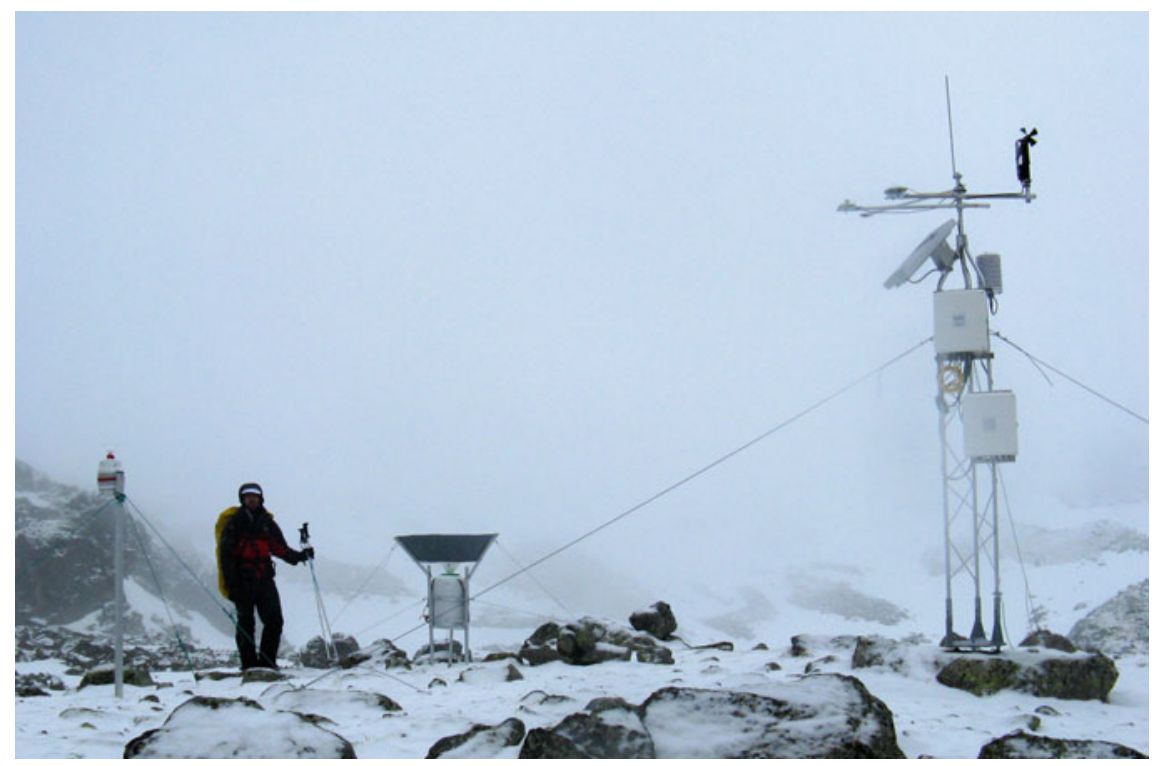

Fig. 1.1 Meteorological and atmospheric deposition monitoring station in Lake Contraix (Aigüestortes i Estany de Sant Maurici National Park (PNAESM), Pyrenees). High mountain nature reserves are particularly suitable for developing long-term studies to investigate the development and consequences of global change on ecosystems. To cope with the local characteristics of the atmospheric forcing, meteorological and deposition stations have to be deployed and maintained with a perspective of at least decades, to provide fundamental information to any other ecosystem study in the mountain catchments (Camarero 2017b). Photography: Lluis Camarero

UVB range (Blumthaler et al. 1997), which may be enhanced by stratospheric ozone reduction (Blumthaler and Ambach 1990); cold conditions may facilitate the condensation of semi-volatile compounds (Grimalt et al. 2001); and they are barriers to air-masses thus they are exposed to long-range transport of substances (Catalan et al. 2013), microorganisms (Barberan et al. 2014) and diaspores (Flo and Hagvar 2013). Although harsh conditions in the high mountains have been a constant for the organisms living there, this does not mean that they are not sensitive to fluctuations. In many instances, a large part of the high mountain organisms may be living at the edge of their respective possibilities; the tree-line illustrates this issue (Korner and Paulsen 2004).

The way in which humans have been occupying and using the mountains have been changing throughout history and locations (Walsh 2014). In many of the ranges around the world, large areas have been modified for pasturing and forestry purposes (Miehe et al. 2014); often reaching a landscape configuration that may appear natural to non-expert analysis. This traditional land use has not been sustained through centuries everywhere, since wax and wane have modified the pressures depending on both societal and climatic factors (Bocquet 1997). During the last decades, high 
mountains are experiencing a large cultural and socio-economical shift in many regions of the world (Ooi et al. 2015). Transport facilities have increased visitors, and tourism has become a significant economic element in the high mountain and around nature reserves (Oian 2013). In parallel, most traditional land uses-once diversified and recurrent - are vanishing as local pressures on mountain ecosystems. Mountain conservation involves a daunting task evaluating exposure and sensitivity to a wealth of exceptionally dynamic pressures. An accurate evaluation is fundamental for defining new conservation goals since a crude estimation indicates that traditional ones may not be possible any longer.

\subsection{Mountain Exposure to Global Changes}

\subsubsection{Climate Change}

It has been suggested that mountains experience stronger cold and warm climatic fluctuations than average lands (Dedieu et al. 2014; Beniston 2006). Despite this may be a matter of debate, there is no question that the recording and perception of warming during the last decades have been observed at many different ranges (Diaz and Bradley 1997). The particularity with mountains is that the altitudinal gradient induces contrasting climates in a short distance. With climate change, the regional means will change, but the altitudinal and other topographically-induced variability may also be modified. All in all, mountains will warm throughout the world (Nogues-Bravo et al. 2007).

In regions with relatively dry average climates, such as the Mediterranean, high-mountains constitute sources of water to lowlands (Boithias et al. 2014). Ascending from plains, one goes across water-driven vegetation to mostly temperature-driven ecosystems. Not only in these mountain ranges but in general, the way in which precipitation will regionally shift appears critical to project potential vegetation changes, including details of the topographical climatic variation in the high-mountain (McCullough et al. 2016). The Mid-Holocene has provided clear evidence that a complete shift in dominant landscape vegetation is possible at sub-millennial time scales (Carrion 2002), with transitional changes at local scales probably occurring over decadal periods. Mountain nature reserves may be submitted to progressive declines in annual precipitation and also to increasing frequency of drought events (Beniston et al. 2007). The character of the shift, either smooth or abrupt, may result in entirely different interactions with other processes, such as pests (Hodar et al. 2003), invasive species (Thomas 2010), pollution (Bogdal et al. 2010), etc.

Even in ranges not expected to experience changes in annual precipitation, warming will change the hydric balance. The seasonal pattern of warming would play a critical role in determining the kind of new situations that ecosystem experience. For instance, summer and autumn warming may lead to seasonal water 
limitation; spring warming to early snowmelt (Moran-Tejeda et al. 2014) and upward shift of the snow line in spring; winter warming to episodic events of melting (Gobiet et al. 2014) and shorter snow duration (Hantel and Hirtl-Wielke 2007); summer snowline uplift to a reduced nival belt (Gottfried et al. 2011), and so on. In general, the shift from snow to rain may have amplifying consequences for the hydrological cycle and the natural processes depending on it (Morán-Tejeda et al. 2017). Floods related to rain-on-snow events may increase (Beniston and Stoffel 2016), at least during a transition period as warming proceed. All things considered, climate change may increase synchrony between ecosystems compared to pre-industrial dynamics, which appears to be the case for forest over large areas (Shestakova et al. 2016).

\subsubsection{Atmospheric Contaminants}

During the last decades, awareness about the accumulation of some persistent organic pollutants (POPs) in high-mountain organisms has been increasing, mainly from fish (Schmid et al. 2007; Grimalt et al. 2001) and pine needles studies (Grimalt and van Drooge 2006; Davidson et al. 2004). The initially uncertainity of measuring high concentrations of some pollutants, far away from the areas where they are produced or used, has given way to understanding the mechanisms related to the semi-volatile character of these compounds (Catalan 2015). Although details may differ from site to site, the preferential accumulation in cold areas, such as the high mountains, is related to the air-water partition sensitivity to temperature for these compounds (Wania and Westgate 2008). They are extremely hydrophobic, so if in solution they quickly adhere to any organic material and thus organisms (Catalan et al. 2004). The toxicological consequences of the POPs bioaccumulation in mountain organisms are scarcely known; there are only a few pioneering studies (Jarque et al. 2015; Quiros et al. 2007).

In fact, environmental dynamics of synthetic substances and their ecological consequences is one of the major unknowns among global change components. The assumed general behaviour may be plenty of challenging particularities for each compound (Bartrons et al. 2012). Conservation biology should pay more attention to the investigation of the potential problem. It may be affecting wildlife in a way still difficult to evaluate, but that could be non-negligible according to the indications provided by some studies in wild predators (Elliott et al. 2012) and domestic herbivores (Shunthirasingham et al. 2013). An added interest to the topic is the interaction of this dynamics with climate warming (Noyes et al. 2009). On the one hand, higher temperatures will decrease the tendency to condensate of these compounds in some mountain areas. On the other hand, high temperatures will increase their release from soils were they might have accumulated. In any case, there will be a redistribution of substances trapped in natural reservoirs [e.g., glaciers, Schmid et al. (2011)] and long-distance air transport will be probably enhanced. New synthetic organic substances are discovered every day (Muir and 
Howard 2006). Even if the substances are not particularly persistent in the environment as much as POPs (e.g. PCBs), the use of some of them in large amounts (e.g. in agriculture) may result in a steady transport to the mountains and the exposition of the organisms there to high concentrations (Weber et al. 2010).

Metals are other atmospheric pollutants that have accumulated in the mountains (Camarero 2017b). In fact, they have a longer history than POPs. Evidence of early pollution in Europe dating from the Roman period and also from ancient times in other parts of the world becomes stronger the more studies on natural registers exist (Catalan 2015). Mountains have also been sites of historical interest for mining provided that ores of different minerals are common. Depending on the economic context even the exploitation of small, difficult to access mines have taken place (e.g. Trou des Romains, Val Sapin, Italian Alps). The regional context of this mining throughout history is well recorded in lacustrine sediments and peats (Camarero et al. 1998). The ecological consequences, if any, of these atmospheric pollutants have not been evaluated yet. In some areas, the accumulation of some trace metals in soils is very high so, under lower current deposition, they have become sources of pollutants to sediments, plants, and animals, rather than sinks (Bacardit et al. 2012). There is a legacy of pollutants in soils that may maintain high pollutant fluxes for some decades.

Ozone depicts a unique case in the global change context. On the one hand, the current decline in stratospheric ozone causes an increase in the UV radiation reaching the ground. In high mountains, the effect is enhanced compared to low lands. First, because the atmosphere is thinner and thus both total and relative UV is higher (Blumthaler et al. 1997); second because many high mountains are above a cloud belt that protects valley lands from high radiation (Blumthaler et al. 1994). However, the direct consequences for the organisms' life of the increase in UV and, particularly, in the more harmful UVB, might not be huge, since mountain organisms have evolved in high UV environments, thus have developed many protective and repairing mechanisms. Nevertheless, UV exposure is repeatedly pointed as a potential factor of some species decline (Mitchell et al. 2015). On the other hand, tropospheric ozone is increasing. At ground level, ozone protective role against UV matters little and what becomes important is its harmful highly oxidative effect (Wittig et al. 2009). Observatories in high mountains have indicated a sustained increase in tropospheric ozone in many areas of the world. It can be considered a global hazard. Indeed, there are mountains particularly exposed to air masses that bring high ozone concentrations from source areas (Elvira et al. 2016). Ozone is harmful both to plants and humans. The effects of ozone on trees may be confounded at first instance with drought effects. It would be reasonable to develop specific surveillance protocols for high mountains, particularly in nature reserves. Thus environmental assessment will provide a double benefit. With climate change, the stratosphere-to-troposphere ozone flux will be modified with latitudinal differences in UV radiation effects and stratospheric ozone (Hegglin and Shepherd 2009). Some technically sophisticated observatories already deal with estimations of trends and global averages (Li et al. 2007; Cristofanelli and Bonasoni 2009; Cristofanelli et al. 2010). Simpler systems may serve as sentinels for conservation purposes, 
and for investigating marked orographical differences within relatively small areas (Burley et al. 2015).

\subsubsection{Long-Distance Atmospheric Fertilization}

Part of the decline in stratospheric ozone is due to the emission of nitrogen oxides to the atmosphere. Nitrogen emissions have many other effects. The perturbation of the nitrogen cycle is probably also beyond the limits of a sustainable Earth system (Steffen et al. 2015). Crystalline rocks dominate in many high-mountain landscapes. Soils and waters on these bedrocks show little acid neutralizing capacity. Therefore, mountains in areas receiving acid deposition due to emissions of sulfur and nitrogen oxides to the atmosphere suffer acidification (Psenner and Catalan 1994). Visible consequences (e.g., fish kills, tree defoliation) had prompt to an international reaction of successful results in controlling sulfur emissions and severe acidification (Catalan et al. 2013). However, nitrogen emissions are still high and difficult to reduce because of their multiple sources-industrial, agricultural and urban. In addition to being acidifying agents, $\mathrm{N}$ compounds are also fertilizers for plants (Stevens et al. 2015). Increasing atmospheric $\mathrm{CO}_{2}$, nitrogen deposition and temperature all point to an acceleration of primary productivity. In recent years, $\mathrm{P}$ atmospheric deposition has also been identified as being enhanced by human industrialization (Penuelas et al. 2013a). Mountain soils and waters are exposed to all these fertilizing agents, which are changing the biogeochemical cycles in the high mountains in a way not sufficiently understood (Camarero and Catalan 2012).

\subsubsection{Biotic Dispersal Enhancement}

Increased transport of goods and people is a feature of the post-industrial society. This has facilitated the dispersal of all kinds of organisms to longer distances and with higher frequency. Mountain natural reserves are increasingly exposed to exotic and invasive species and new diseases and pests (Pauchard et al. 2009). Amphibians have been particularly suffering this pressure. Chytridiomycosis has been spreading quickly around the world and devastating some of their populations (Wake and Vredenburg 2008). The interaction between pests and climate change is a major source of uncertainty in conservation. Tree populations at their ecological limits may be more prompt to infection, which may accelerate and otherwise slow substitution of species (Camarero 2017a).

In some ranges, fish stocking is the primary pressure on amphibians (Miró and Ventura 2013). Human enhancement of fish dispersal in mountain lakes, which are naturally fishless, is a complex behavioral and economic phenomenon where ignorance and interest play significant roles and poses major difficulties to conservation (Ventura et al. 2017). In the current shifting environmental conditions, 
which are challenging the foundational goals of a natural reserve, the role that leisure may play becomes a matter of discussion. With rising inhabitants, the number of visitors to natural reserves will continue increasing, both from nearby and long-distance origins and with different motivation, including from purely touristic attraction to scientific interest. Planning and protocols to prevent facilitated dispersal of undesired organisms should develop and spread at a quicker pace than the problems are diffusing.

Enhanced dispersal also includes the controlled introduction of new species, or re-introduction of formerly extinct species, most typically of vertebrates. Reintroducing some of these emblematic species from more or less remote populations is now feasible (Fig. 1.2), and adds new socio-economical interest to the areas beyond conservation purposes and, in parallel, the need for new managing measures (Palazón 2017). Consequently, some key species in mountain ranges are becoming more and more managed.

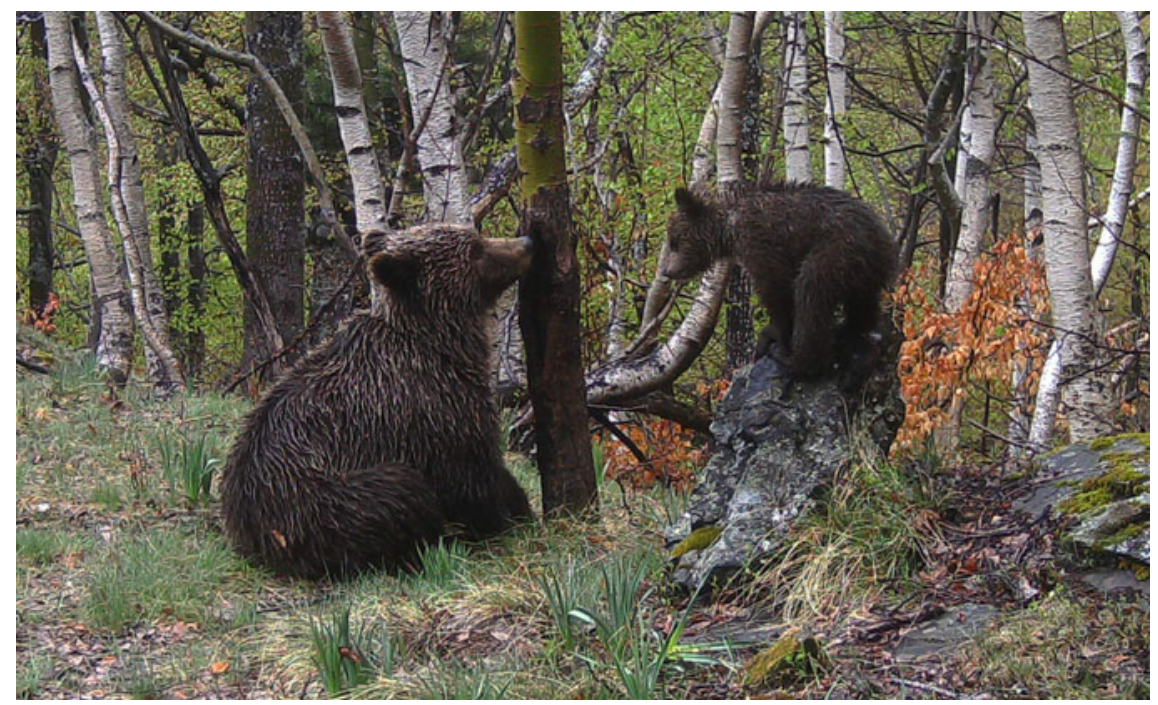

Fig. 1.2 A female brown bear with a cub of the year in the Pyrenees (September 5, 2016). Beyond the ecological consequences, the reintroduction of large carnivorous in areas where they have been extinct or nearly so indicates a change of the societal attitude towards nature of valuable symbolism. The last female bear from Central Pyrenees died in 2004 and the last male in 2010 (Palazón 2017). The current bear population was reintroduced from a set of individuals captured in the Balkans (Slovenia) and released in the Pyrenees in 1996-1997. There was only one male born from a released Slovenian male and the last Pyrenees female. In 2015, the Central Pyrenees subpopulation had more than 30 bears identified. Photography: Departament de Territori i Sostenibilitat, Generalitat de Catalunya 


\subsection{Mountain Exposure to Regional Changes}

Economic globalization has brought many changes to the local and regional socio-economical context of mountains. Low cost of transport has modified commercial yields in forestry, mining and mountain pasturing. On the other hand, mountain activities for leisure are exponentially increasing. Conservation faces global change hazards exposed to regional socio-economic changes, which ultimately will also be conditioned by climate change.

\subsubsection{Pasture Shifting Systems}

Mountain pasturing dates from several millennia ago in some ranges (Schmidt et al. 2002; Pèlachs et al. 2017). Depending on the socio-economic context of the mountains the intensity and type of pasturing have been fluctuating across time. Mountain archaeology has provided evidence of the early Neolithic use of rock shelters and caves used as protections for sheep and goats in European mountains (Gassiot Ballbè et al. 2017). No signs of ecological impact have been associated with them yet. The opening of extensive pasturing areas at altitude during the Bronze Age is clearly documented by archaeological sites and palaeoecological records from lakes, bogs, and stone fences and shelters (Fig. 1.3). This use of high-mountain meadows during millennia cannot have been ecologically innocuous; indeed, it may even have constituted a selection factor favoring particular plant treats, species and assemblages. This is a scarcely studied subject, as mountain pasturing has usually been seen by ecologists as a traditional activity rooted in medieval times. Also, the biogeochemical cycles in mountain meadows have been probably accelerated by large herds pasturing during a portion of the year, whose winter survival is assured by migration to much lower altitudes or far-away locations. This has led to much higher herbivorism at the high mountain than in non-herding situations, where much smaller wild herbivore populations survived resisting winter conditions with short altitudinal migrations. With the development of high mountain pastures, the $\mathrm{C} / \mathrm{N}$ ratio distinctly declined in sediments of the lakes in the catchment, probably reflecting changes in soil conditions (Schmidt et al. 2002).

The way to manage pasturing is different from range to range (even from valley to valley), and it has been shifting through time according to societal changes (Berrocal et al. 2014). A general tendency seems to have been increasing the number of animals per field shepherd by joining several small herds into a large one during summer pasturing; even that the ownership was maintained by many individuals. This seems to have been a tendency as societies have become more complex from the Bronze to Middle Ages and modern times. Many protected areas include large pasturing meadows, whose management has been a matter of debate. Arguments in favor of maintaining traditional practices are not probably aware of the real extent of this adjective. Ironically, relatively recent shifting from sheep to 


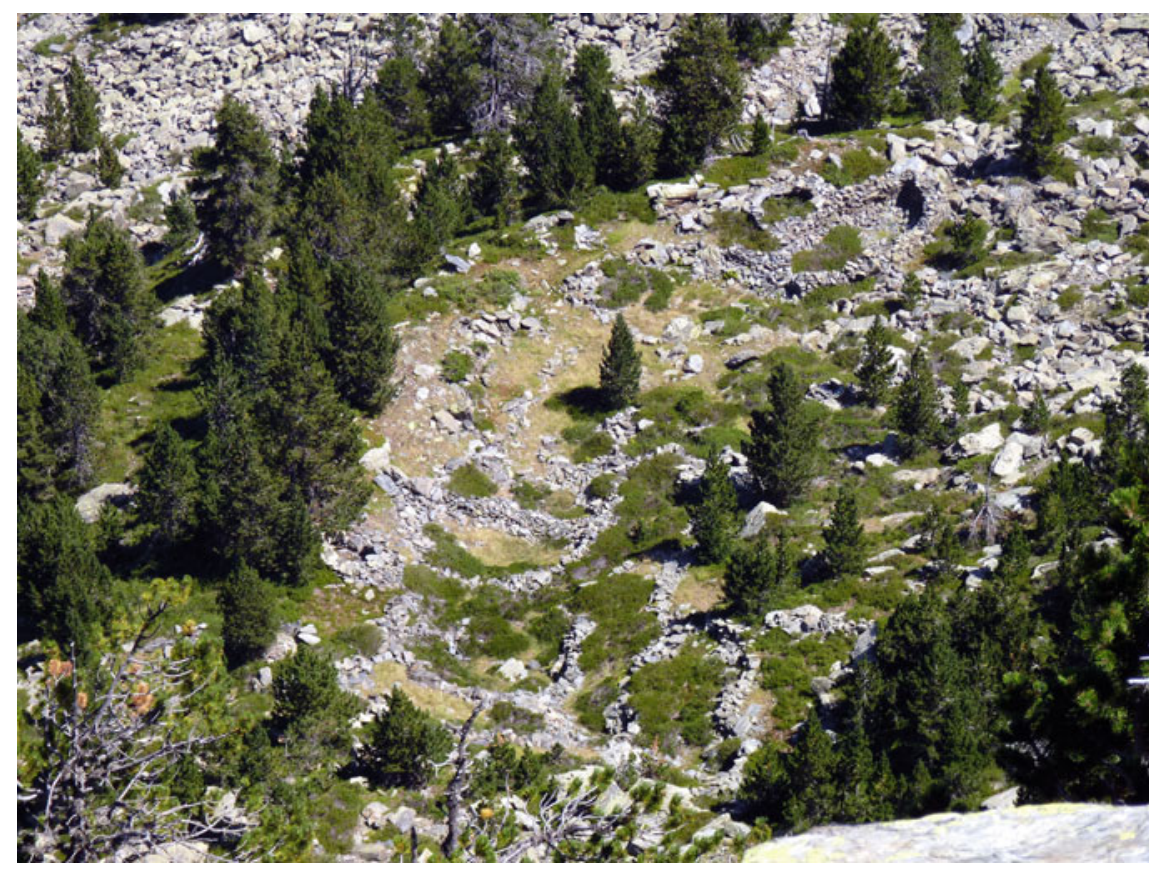

Fig. 1.3 Despoblat de Casesnoves archaeological site. Medieval human occupation at $2225 \mathrm{~m}$ a.s. 1. that lasted until the 13th century (PNAESM, Pyrenees). Although the high mountain landscape retains a lot of the wilderness character, the human footprint can be recognized in many ranges of the world. Archaeological evidence indicates an early Holocene occupation (Gassiot Ballbè et al. 2017) and a development of a cultural landscape at least since the Bronze Age. Natural and cultural heritages may coexist in high mountain nature reserves. However, management decisions should not respond to pressures based on weak arguments about the merits of traditional uses. Nature reserves should promote the proper understanding of the ecological incidence of humans on high mountain ecosystems and landscape across time, but not necessarily reproduce them. Photography: Grup d'Arqueologia de l'Alta Muntanya, Archive of the Aigüestortes i Estany de Sant Maurici National Park

cows has raised new concerns in some areas. The two species influence the meadows in an entirely different way, thus changing the vegetation and soil processes. Soils in the mountains are usually thin, and meadows provide the areas with the largest capacity for carbon storage (Garcia-Pausas et al. 2017). All in all, nowadays the so called traditional uses have seen sharp shifts, in the form of abandonment of extensive, low-income activities. This has led to encroachment of less productive pasture into shrub land and to secondary woodland (Lasanta-Martinez et al. 2005). To allow forest recovering vs. maintaining sheep or cow pasturing may become an issue for some conservation reserves that are fairly conditioned by a cultural view of the mountain, and do not consider enhancing wilderness as a primary goal (Fig. 1.4). On the other hand, the scenario to manage may change in a faster way than the time required for implementing protection 
measures (Garrard et al. 2016). Indeed, rapid economic development related to the climatic shifts may be faster changing the landscape than the vegetation natural response. Projections of climate change effects on nature reserves should include potential new economic scenarios in the region.

\subsubsection{Conservation Versus Extraction}

Through history, the high mountains have been regarded and used by humans as a source of goods (timber, rangeland, hydropower, fishing, etc.), with the particularity of being a space marginal to the permanent human habitat. Thus, being strongly subject to seasonality, human settlements have been placed for most time at low altitudes [but see Pèlachs et al. (2017)]. In contrast with other exploited ecosystems, high mountain apparently maintained a high degree of wilderness, to some extent

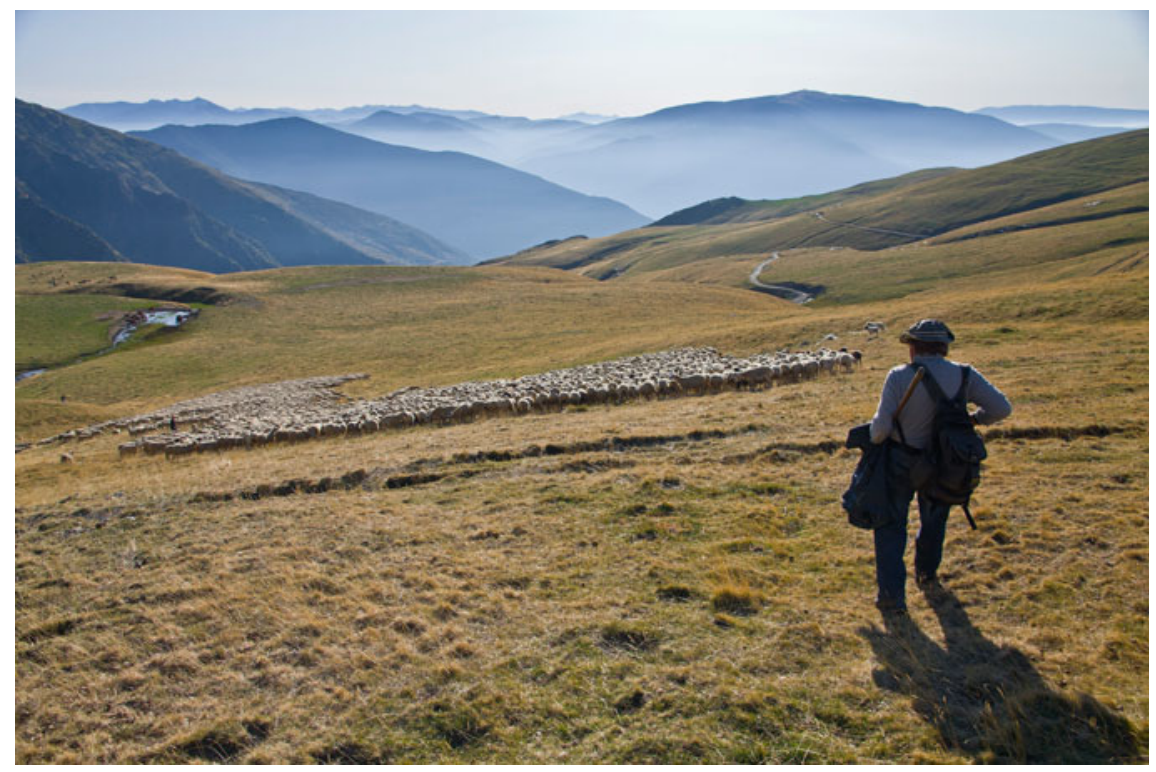

Fig. 1.4 Sheep flock in the Vall d'Àssua (Pyrenees). Enhancement of high altitude pasturing meadows lowering the treeline may have lasted for several millennia in many mountain ranges of the world. This practice had to have ecological and also evolutionary implications, which are still scarcely understood. The current socio-economic context of the mountains is changing the land use. This driver of ecological shifts is still stronger than climate change in many regions. Conservation requires distinguishing between the two drivers and eventually understanding their interaction (Pèlachs et al. 2017). Photography: Jordi Peró, Archive of the Aigüestortes i Estany de Sant Maurici National Park 
related to the imposed winter cessation of activities and to the noticeable proportion of land scarcely or not at all exploitable (rocky and scree areas, alpine heathland, fell-fields, etc.). However, growing evidence is emerging on the profound shifts caused by human activity at several levels of the high mountain wilderness, such as depletion or vanishing of large mammal's populations, alien fish introduction, uneven grazing by domestic herbivores, overuse of running waters, or forest exploitation.

Up to some decades ago, exploitation was thought as limited to shape semi-natural ecosystems, hampered by the limitations inherent to the environment. Short seasonal forest growing led to longer logging periodicity in subalpine woodlands than in lower altitude forests, and grazing intensity necessarily remained lower than the resprouting capacity of grasslands. However, as high mountain ecosystems become more finely analyzed, more footprints of exploitation practices emerge to identify these activities as key factors in the current ecosystem functioning. The present structure and functioning of woodlands are in many cases a delayed response to ancient logging. For instance, this included recent tree mortality in the Pyrenean Abies alba forests, a phenomenon predisposed by historical logging that enhanced dense tree populations and induced by recent climatic changes (Camarero 2017a). Similarly, shifts in alpine grazing have changed grassland structure and composition (Komac et al. 2014).

Forestry is the most controversial issue concerning resource extraction in the mountains; particularly if a view of maintaining a cultural landscape predominates above wilderness enhancement (Agnoletti 2007). Where nature reserves include large forested areas there is little argument for selective extraction, since they can maintain natural dynamics - including catastrophic events. However, in the tiny reserves of many European ranges forest management may be an important issue. Arguments against forest aging and consequently selective cutting may appear even with the conservationist support. Global change tendencies and the need for pest control may increase the supporters of this latter view.

Mountains are full of natural resources susceptible to economic exploitation. As a result of the orographic processes many ranges are rich in metals. This was very early appreciated, and even in dry high mountains (e.g. Sierra Nevada, Iberian Peninsula), where high-altitude agriculture or herding was not particularly suitable, mining was an old practice (Martin Civantos 2014). The techniques for mineral extraction in former times were not particularly concerned with the environment. As a consequence, a legacy of pollution is maintained in the soils affected by atmospheric transport from the mining sites in the region. Environmental history studying palaeoenvironmental registers is progressively unveiling the distribution and patterns of this old extractive activity (Catalan 2015). In some valleys, rich in metals close to the surface, an associated metallurgic industry has impacted forest to provide wood fuel (Pèlachs et al. 2009). This activity also has a changing dynamics of centuries; current landscapes bearing apparently well-develop forests may hide a history of several centuries of exploitation. Historically, mining industry/business was firmly driven by economic constraints, compared to pasturing or agriculture that could be closely related to the local domestic activities. Therefore, except in 
mountain where there is still an economical yield, mining becomes a historical issue rather than a conservation problem. The historical heritage that mining may have left on the mountain is an on-going research subject. Technological improvements have usually lead to increased extraction and atmospheric pollution when resources of economic value exists (Uglietti et al. 2015). Unfortunately, environmentally careless mining keeps going in some ranges of the world nowadays (Pond et al. 2008; Wickham et al. 2013).

The increase in human populations and water demand, both for cities and agriculture irrigation, has raised the value of mountains as water source. Large regions, even whole countries, may depend on the precipitation in faraway mountains [e.g., Himalayan region (Xu et al. 2009)]. Glaciers may provide a year-long regular water supply to areas of marked seasonality in precipitation. Some large cities in the Andes depend on reservoirs fed by such glaciers, which shrinking and final disappearance may cause large societal problems (Carey et al. 2014). Probably, little can be done on glacier preservation at this stage of climatic change (WGMS 2015; Zemp et al. 2015). Thus plans for long distance transport to these cities are required, which may change hydrological regimes in other areas, and challenge conservation of mountain ecosystems.

In some mountains, there has been a traditional management of water for irrigation purposes. An extraordinary example is the Sierra Nevada (Iberian Peninsula) acequia system built during the medieval Muslim period (Martin Civantos 2014). Thousands of kilometers of small channels bring water from the mountain (sierra) to the irrigation fields (vega), starting at about $2000 \mathrm{~m}$ a.s.l. and modifying the hydrological regime of the lower part of the mountains. Other channels at higher altitude (i.e., careos) drive water towards groundwater to increase spring supply. This change in the hydrology has to have altered natural vegetation. A large proportion of the modified area is now part of a National Park and nature reserve surrounding it.

Hydrological extraction has been more recent in the mountains located farther from areas requiring high amounts of water supply, mostly starting at early- or mid-20th century and associated with the development of hydropower stations. In this case, lakes and streams have been particularly exposed to alterations (Catalan et al. 1997). Surface connectivity between lakes has been enhanced by undergrown galleries that may even connect lakes in different watersheds. In some areas, little control of water level regulation or failure of old valves have produced huge water level oscillations in lakes, resulting in severe impacts. The temporal overlapping between this kind of industrial exploitation of mountain resources and the declaration of some mountain parks have led to odd situations in which both coexist in the same area (e.g., Aigüestortes i Estany de Sant Maurici National Park, Pyrenees). Beyond obvious impacts on the most affected lakes and streams by seasonal desiccation or strong water oscillations, flow reduction and smoothening of the seasonal fluctuations tend to produce a banalisation of the aquatic biota. Landscape visual impacts are usually scarcely compatible with conservation reserves. Yet the ultimate goal should be the eradication of this extraction activity from natural reserves, actions against light contamination and general visual impacts of buildings 
and services are easily achievable actions. Climate change may exacerbate debates between conservation and water extraction even in the mountains with water surplus (Beniston 2012).

\subsubsection{Tourism and Sport Pressures}

In many mountain valleys around the world, tourism is growing as an economic component replacing productive or extractive activities (Nyaupane et al. 2014). Tourism development has led to separation into different categories such as ecotourism, sustainable tourism, wildlife tourism, nature-based tourism, heritage tourism and cultural tourism (Rotherham 2013). Each of these categories has their own idiosyncrasy, which should be taken into account in the high mountain conservation planning.

Nature reserves become a reclaim for the tourism sector. Declaration of new protection areas sometimes includes among their benefits that they will favor this economic field. Handling visitor's affluence may become a primary issue for some natural reserves of relatively reduced size or without possibility to diversify visitors towards different zones. Access to mountain reserves usually follows some main routes that become both a constraint and an opportunity for managing the number of visitors. To traditional mountaineers, urban inhabitants on holidays and outdoor long-distance sports practitioners provide new challenges to conservation. An accepted self-responsibility for the risk that mountains constitute, which mountaineers and people working in the mountains had, is being replaced by a safety delegation to the community. This may increase the gap between visitors and locals. To an increasing degree, rural landscapes are being transformed into sites for leisure. Even though tourism is welcomed as a rescue plan of rural mountain economies in decline, it may at the same time be associated with unwanted changes. In the cases in which the nature of these landscapes is labeled as wilderness by conservationists and tourist industry alike, inhabitants of local communities may perceive that the social and cultural aspects of the landscape they strongly identify with are being disregarded (Oian 2013). This applies, for instance, to hunting and angling in nature reserves and neighbouring areas for animal population control or leisure but not for local consumption.

Climate change is modifying conditions at high altitudes, changing the spatial distribution of risk and accessibility. Global factors cannot be mitigated locally but improved management practices that aid local conservation and development in this high mountain ecosystem are required (Garrard et al. 2016). At lower altitudes within large ranges, a shift from traditional practices to a more diversified blend of agropastoralism, tourism services, and cash-crop production may become adaptive for local economies (Konchar et al. 2015). Conservation must find its place within this changing dynamics. On the other hand, in mountain ranges supporting a winter snow industry, changes in snow deposition and snowpack persistence may result in new demands upon preserved areas, enhancing social debates about conservation 
and economic sustainability at local and regional scales (Beniston 2012). Sensitivity analyses of snow patterns to projected climate change may help to anticipate conflicts; not only altitude matters for snow distribution (Uhlmann et al. 2009).

\subsection{High Mountain Idiosyncratic Sensitivity}

\subsubsection{Temperature Versus Water}

The elevation increase in mountains provides an associated decline in temperature, atmospheric pressure and land area availability. Therefore, in a short distance environmental conditions change markedly providing the cues for a highly diverse landscape and richness in organisms. This marked gradient also determines the high sensitivity of mountains to climate change. The great diversity in forest formationsand vegetation in general - is at expenses of a lower available surface for each of them compared to plains, where similar conditions extend over large areas. Therefore, climate change may imply a significant modification of suitable areas for a particular type of forest, scrub or meadow (Dullinger et al. 2012).

The orographic barriers tend to increase precipitation at the slope facing the ascending air masses. Mountains in general are, therefore, richer in water resources than surrounding low lands and usually become a net source of water for the latter. If air masses rich in water are mostly coming from the same direction, the vegetation contrast between mountain slopes may be remarkable. Consequently, mountain vegetation is particularly sensitive to changes in direction and average moisture content of air masses. In contrast to temperature, there is not a global pattern of precipitation change with altitude (Körner 2007). In the temperate zones of the planet, precipitation increases with elevation, either as rainfall or snow. But in other parts of the globe the tendency can be the opposed, or the maximum can be at intermediate levels. The mean altitude of the surrounding ranges is another factor determining the characteristics of the altitudinal precipitation pattern. If climate warming forces in a similar direction most of the mountains on the planet, changes in air mass direction and moisture would show more distinctive regional (even local) characteristics (Engler et al. 2011). Whereas long-term conservation plans can be based on general warming projections, tendencies on precipitation would be better assessed locally, and monitored at different sites in nature reserves with valleys facing different directions (Beniston and Stoffel 2014).

A critical issue in areas with current positive water balance, where temperature drives vegetation distribution, is whether changes in climate will bring to a situation of water deficit during vegetation growth periods. The short-term and long-term response of mountain tree populations to episodic droughts are still scarcely studied (Cocozza et al. 2016). Nature reserves entirely or partially within this situation would face the main challenges in the near future. Drought episodes may compensate for any fertilizing $\left(\mathrm{CO}_{2}\right.$ and $\mathrm{N}$ deposition increase) or warming growth effect that may exist upon tree species usually controlled by temperature rather than 
water availability (Camarero et al. 2014). Vegetation on mountains with current water limitation may be more resilient to extreme drought events (Herrero and Zamora 2014), albeit that recurrent episodes may produce a progressive loss of resilience (Lloret et al. 2004). Long-term palaeoecological evidence warns about non-linear responses to water availability (Anderson 2012).

Most temperate mountain ranges are characterized by an altitudinal partition of the slopes during spring into a snow-free belt and a white upper belt (Fig. 1.5). In fact, there is a changing role of temperature and precipitation on snowpack. At lower altitudes, temperature influence predominates and precipitation is a better predictor of snowpack variability above certain altitudinal threshold (Moran-Tejeda et al. 2013). As climate warms, the threshold will move upwards. Warming may also affect heavy snowfall frequency differently with altitude, increasing the contrast between the upper snow belt and the lower altitudes with a shorter snow period (Ignacio Lopez-Moreno et al. 2011).

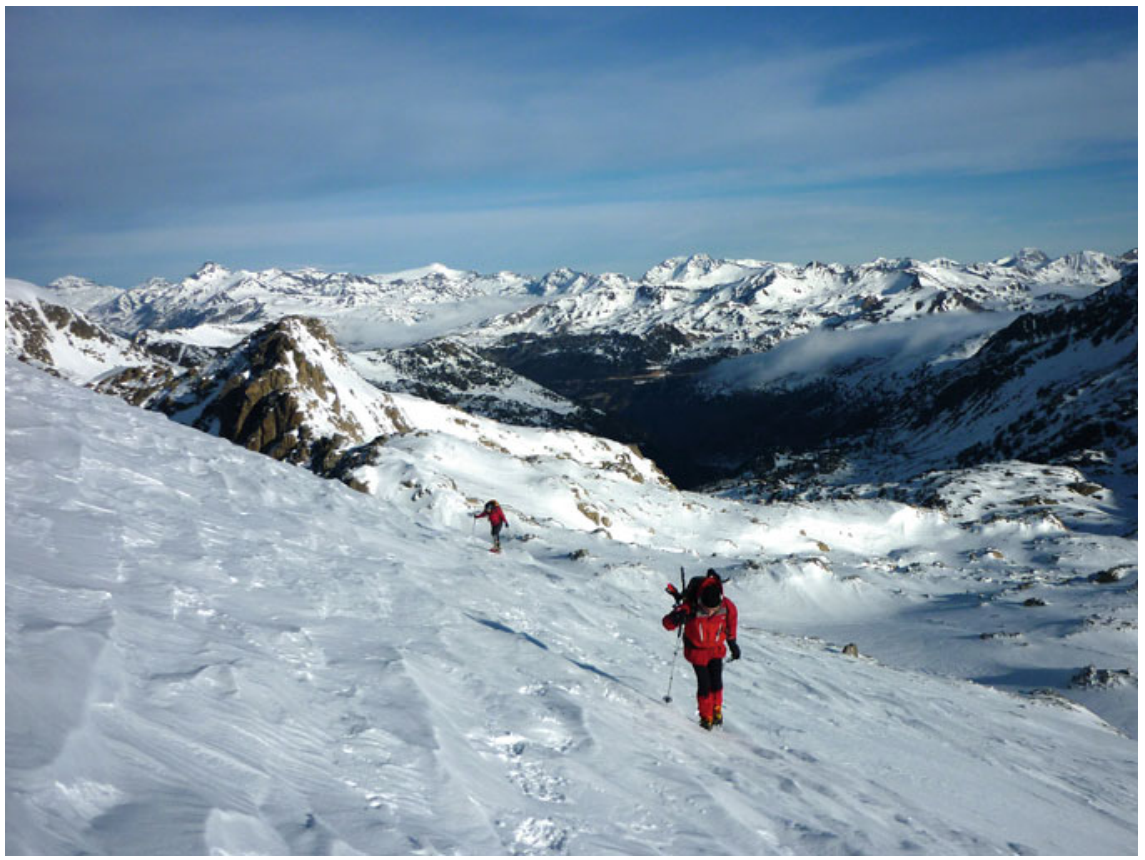

Fig. 1.5 Landscape view of Val de Saboredo (Aran, Pyrenees). The typical spring division of the high mountain into a white snow belt and a lower one where fields flourish will probably come earlier and extend its duration with climate warming (Morán-Tejeda et al. 2017). This shift increases potential risks (avalanches, floods) beyond the non-expert perception. Nature reserves should be prepared for handling these increasing likely situations. Photography: Francesc Xavier Bové Carbó, Archive of the Aigüestortes i Estany de Sant Maurici National Park 


\subsubsection{Persistence Versus Migration}

The high mountain biota includes cases of log-term persistence within a given range of some species. They went through contrasting climatic conditions such as those corresponding to the Quaternary succession of cold and temperate periods. In this sense, some ancient plant and animal endemics have apparently remained from Pliocene onwards roughly within their present range (Schmitt 2017). Interestingly, most of these species, called paleoendemic, correspond to more or less isolated tips in phylogenetic trees and nowadays are found in conservative habitats (Garcia et al. 2012) and are focus of conservation biology research (Segarra-Moragues and Catalan 2010). Aside from these survivors, however, most probably there were close relatives that vanished through changing ecological conditions. In parallel, more dynamic ecosystems (e.g., grasslands) must have enhanced radiating speciation, which is well exemplified in rich taxonomic complexes exhibiting narrow endemicity at the levels of species or lower (García and Gómez 2007). Therefore, a high mountain with fragmented landscapes in which different habitats are densely arranged has been a noticeable arena for various biological groups where fine-scale isolation has favored speciation. All in all, the altitudinal gradient imposes contrasting environmental conditions and any overall shift in climate results in pressure upon the current altitudinal species distribution (Fig. 1.6).

In simple terms, the response to an environmental change beyond the ideal conditions for a species consists of two options (Berg et al. 2010). Either persisting by acclimation (and eventually adaptation) to the new situation (Lapenis et al. 2005; Reich et al. 2016) or migrating following the direction of suitable conditions for the species (Hickling et al. 2006). The actual response depends on both the characteristics of the species and the pace at which environmental changes occur (Theurillat and Guisan 2001). In extreme cases, a third option may occur, the sudden collapse and local extinction of the population (Penuelas et al. 2013b).

With warming in the mountains, we can expect an upwards shift of the populations. This may apply from flying invertebrates (Konvicka et al. 2003) to trees (Seppa et al. 2002). However, the time response may be markedly different (Dullinger et al. 2004), with a variety of factors playing a role. Not only matters the capacity for displacement and generation time, but also the interaction with other species (Laiolo and Obeso 2017). Dynamics at ecotones between mountain forest belts is particularly difficult to predict (Dullinger et al. 2005) and simulate (Wiegand et al. 2006); the two, or more, tree species implied may not be responding in the same way at the climate change (Rabasa et al. 2013). Therefore, we can expect not only the displacement of the vegetation in the mountains, but also variations in the relative thickness of the belts, or even the number of belts. At present, except for the top mountain (Rixen and Wipf 2017), vegetation response to climate change may be still obscured for concurrent land use shifts. The response of invertebrates may be less ambiguous at the current stages of mountain warming (Wilson et al. 2005). The different velocity of reaction may be causing a rearrangement of species interactions, which increases the difficulty in predicting the ecological outcomes of 

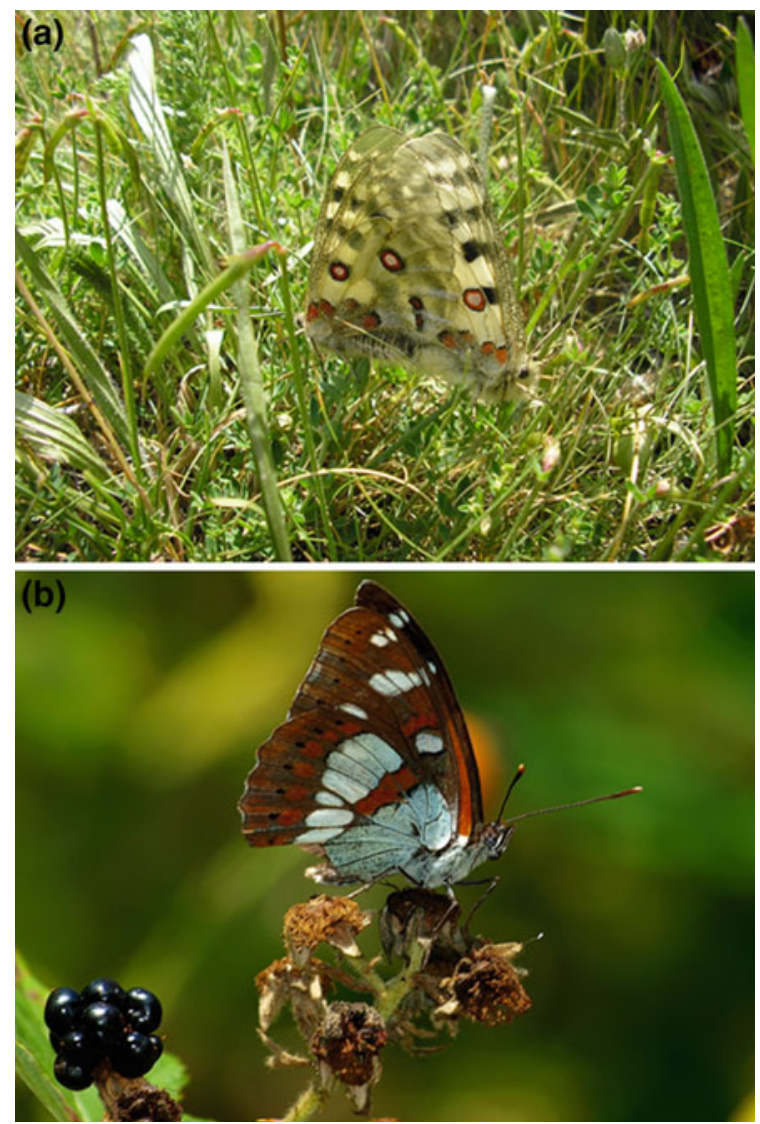

Fig. 1.6 Parnassius apollo (a) and Limenitis reducta (b) from Aigüestortes i Estany de Sant Maurici National Park (Pyrenees). Parnassius apollo has experienced strong regressions in its lower altitudinal limit in France and likely in many southern places of the Iberian Peninsula. The regression is related to a shorter snow cover duration and thus thermal insulation of the immature instars. On the contrary, the Mediterranean species L. reducta may be expanding its altitudinal range in the mountains (C. Stefanescu, com. per.). Butterflies and other invertebrates provide early evidence of nature's response to climate change in the mountains. Although climate warming will change the distribution of the biota across altitude in most of the mountains of the world, not all the species will respond in the same way and at the same pace (Laiolo and Obeso 2017). They possess different capacities to withstand changes and to migrate. Short living and motile organisms are responding in a faster way, and we can expect a long period of continuous rearrangement of the interactions among them. Nature reserve aims have to switch from a purely conservative strategy towards a stewardship of the changes that may happen. Photography: Marta Avizanda, Archive of the Aigüestortes i Estany de Sant Maurici National Park

climatic change (Tylianakis et al. 2008). However, one should also consider that mountain landscapes have gone through marked climatic fluctuations even in recent time (e.g., Little Ice Age), so fixed stability in the species interactions and 
assemblages may be the exception rather than the rule. Species with two altitudinal fronts in their distribution in the mountain may show different predominant processes in each of them. Dispersal may dominate the 'leading edge,' whereas in the 'rear edge' acclimation, adaptation, and genetic drift may predominate (Hampe and Petit 2005). Nature reserves may provide key sites for studying these processes.

\subsubsection{Regional Fingerprints}

There are many features in common around the mountains of the world. On the other hand, each range is different. Even at a relatively short distance, the environmental and socio-economical context of the mountains may differ and with them so do the risk and sensitivity to perturbations. A paradigmatic case is the contrast between the surrounding ranges at the north and south halves of the Mediterranean Sea. Roughly, temperature controls northern vegetation through limiting growth period, whereas water deficit shortens biologic activity at the southern areas. The idiosyncratic aspects may extend to concepts apparently clearly established. The available land area at high altitudes is lower than at montane stages, for instance. However, what happens at medium altitudes may largely differ between ranges. One can find all sort of altitude-areal distributions affecting the upper limit of montane vegetation belts, with contrasting implications in case of upward migration of the montane species (Elsen and Tingley 2015).

\subsection{Conservation Synergies and Challenges}

The combination of exposure and sensitivity determines the eventual vulnerability to environmental changes of the landscape and ecosystems of National Parks and nature reserves in high mountains. Due to the variety of large-scale and local changes to which most reserve areas are currently exposed, the achievement of conservation synergies may be the general goal for natural reserves. The challenge is how to handle the different trade-offs that the regional context may define.

\subsubsection{Conservation Versus Stewardship (Franciscans Vs. Benedictines)}

The declaration of nature reserves and, notably, National Parks was rooted in a concept of stable nature in which the (only) perturbing element was human activity. It was assumed that controlling the latter influence, conservation of landscape, ecosystems, and emblematic organisms would proceed on their own. Today, 
direct human pressure around the reserve areas is still a major problem to deal with for conservation in many places. A radical conservationist position (Franciscan) might be useful in front of local and regional socio-economic influences. But it is certainly useless when the change is driven at much larger scale, exceeding any local or regional countermeasure. Conservation becomes a matter of stewardship of the changes (Benedictines position) in agreement with goals at planetary scale (Steffen et al. 2011). The first step is acknowledging the situation. Climate change is indeed occurring and, whatever the final mitigation of the problem, significant local changes in species distribution and ecosystem dynamics will occur.

A new primary goal of conservation is to handle a smoother transition as possible to new states. This requires the projection of the potential changes and understanding the dynamics leading to them. As we are immersed in the dynamics, this exercise has to be permanently recursive. Migration and invasion would become current issues in nature reserves, and decisions on how to handle them would be better if planned in advance. The principles of nature reserve stewardship have to be developed keeping in mind the multifaceted essence of global change and the mountain idiosyncrasy to enhance some of them. Three basic strategies have been suggested to make the best use of current understanding in an environment of inevitable uncertainty and likely sudden change: reducing the magnitude of, and exposure and sensitivity to, known stresses; focusing on proactive policies that shape change; and avoiding or escaping unsustainable social-ecological traps (Chapin et al. 2010). Likely, all conservation measures are vulnerable to projected changes, but also they should involve sources of adaptive capacity and resilience that can sustain active stewardship of nature reserves.

Climate shift in mountains may result in an extinction debt to pay decades ahead (Hanski 2013). Decisions would have to be taken to what extent it merits to fight against species disappearance that sooner or later may occur (Dullinger et al. 2012). Ecological knowledge here becomes critical, and there is an increasing demand for assessments considering the details of the species distribution. Nature reserves can be just a small portion of the territory occupied by a particular species, but within which actions can be undertaken. As long as a species predicted to become extinct still persists, there is time for conservation measures such as habitat restoration and landscape management (Kuussaari et al. 2009). Standardised long-term monitoring (Zamora et al. 2017), more high-quality empirical studies on key taxa (Fig. 1.7) and ecosystems, and further development of analytical methods will help to quantify the extinction debt better and to more successfully protect mountain biodiversity.

The water balance will certainly play a significant role in mountain reserves' fate. Warming will increase growth temperature and thus water demand; drought risk will increase even in areas with average positive water balance. Does it make sense to undertake mitigation engineering measures? Climate has oscillated enormously during the last million years. Many mountains have been glaciated and deglaciated several times. Fragmentation and refugia during harsh periods explain the current distribution of many species and biogeographical paradoxes among sister species (Schmitt 2017). Do we have the knowledge and tools to identify potential refugia within nature reserves (Gavin et al. 2014)? This could be a main task in conservation research for the near future (Birks and Willis 2008). 


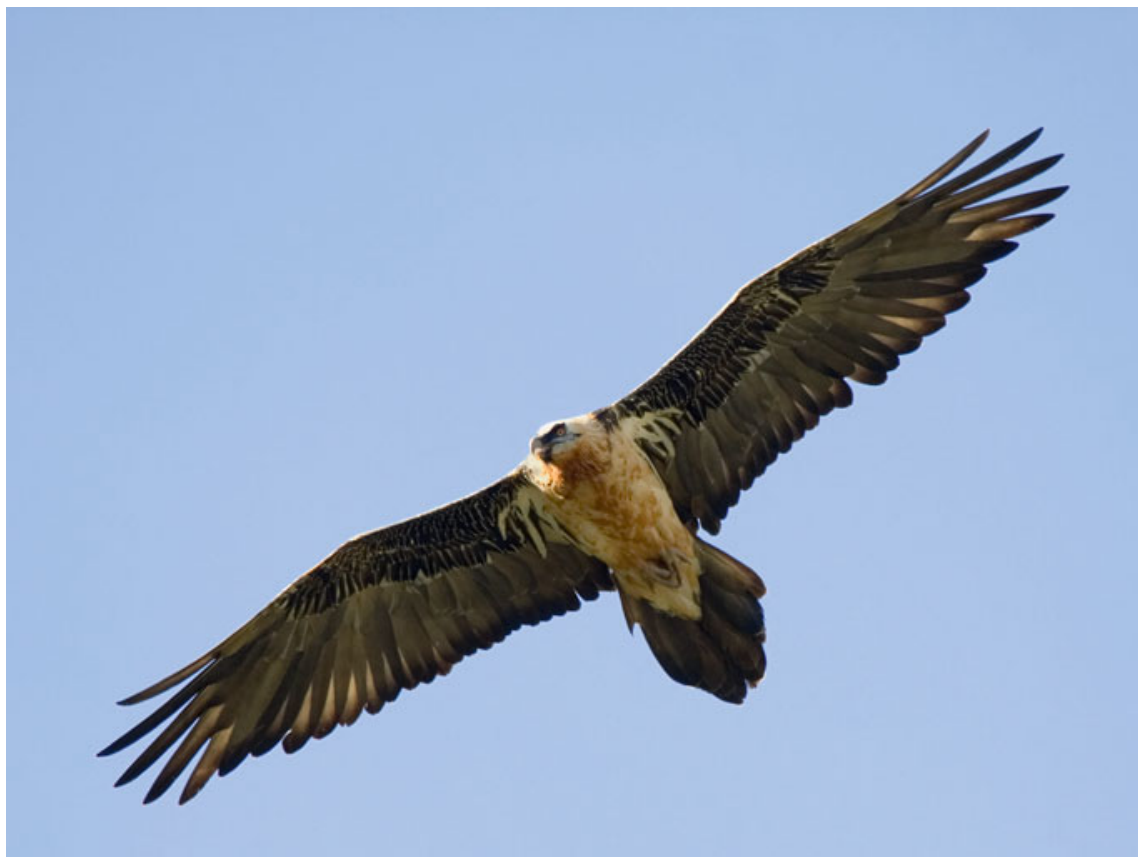

Fig. 1.7 Bearded vulture (Gypaetus barbatus) in Aigüestortes i Estany de Sant Maurici National Park. There are species that play a key role in ecosystem dynamics and, at the same time, become flagship organisms for conservation, either in general or for a particular nature reserve. They attain a high symbolic value both for the scientific community and the population in general. Correct management of these species requires accurate knowledge of their behaviour that needs to be based on long-term research plans (Margalida 2017). Nature reserves are the appropriate scenario for sustaining this type of studies. Eventually, this will facilitate more objective management decisions. Photography: Mario Lancha. Archive of the Aigüestortes i Estany de Sant Maurici National Park

On the other hand, molecular studies may identify priority areas for conservation of the genetic resources of endangered species (Petit et al. 1998).

Conservation has a strong imprinting of the habitat concept. It has been useful for mapping, and a great effort has been put in habitat classification. Patterns of habitat invasions are consistent between regions and some of the high mountain habitats are among the less susceptible to invasion [e.g., heathlands and high-mountain grasslands (Chytry et al. 2008)]. However, about the habitat concept and the interaction between species in general, there is a marked influence of the Franciscan conservation view. Habitats are sometimes erroneously thought as places to be filled with particular species. In fact, it may be argued the opposed, the species make the habitat (Rosenzweig 1995). One may recognize different habitats because they hold different species but would not make any distinction if the same species, or a subgroup of them, were filling the space. The distribution of species will certainly change at a different pace, thus rearranging the current interactions at 
local and regional levels. Conservation will have to deal with that. Coexisting species will not migrate at the same pace with climate change, they even may move in opposite directions if some migrate with the gradient and other counter it (Laiolo and Obeso 2017).

There is a wealth of information about ecological changes with climate fluctuations and human land use in the mountains that still requires a deep analysis beyond patterns' description. Progressively, environmental history is providing a better temporal and spatial resolution about the changes occurred in the mountains during the Holocene (Pèlachs et al. 2017). Yet we may be switching towards a situation without analogues in the past, during this transition we may face situations that similarly occurred during the last 10,000 years. Introducing a long-term historical perspective (centuries to several millennia) in the tool box of mountain conservation management appears as a sensible measure to achieve a correct compromise between observation and action.

\subsubsection{Loss of Uniqueness}

Natural reserves are proud of being representative of the natural values of a particular territory and landscape, but also they are selected because they hold elements of singularity. Scenic values have not to be dismissed (Fig. 1.8). Sometimes the singularity may be more aesthetical than substantial (e.g., certain erosive forms). The very term "National Park" tracks back to some of the initial triggers for the creation of nature reserves during a historical period of effervescent national feelings (Radkau 2008). Identity was reinforced protecting areas of "unique landscape." These scenic values are still perceived as a primary value for visitors to mountain nature reserves (Schirpke et al. 2013). Abandonment of traditional land use may lead to more homogenous landscapes, which may be perceived negatively by visitors. Thus regional mountain planning and political decision makers should make compatible demands from the wilderness, and cultural landscape conservation visions. This is not an easy task. It requires the understanding of nature and socio-economic dynamics at multiple scales. In many ways, the global challenges have its equivalent at regional and local scales.

High-mountains, particularly those in ranges of intermediate size, become territories with a collection of communities and species that mostly differ from those dominant in low lands and middle mountains. This applies in particular when the elevation is in a dry region so that large differences in water availability are added to the altitudinal thermal gradient. In areas without water shortage, warming will produce an uplift of the vegetation belts with the risk of losing the high-mountain character to some extent (Rixen and Wipf 2017). An extreme situation will be the collapse of the alpine flora in a few submits and its impoverishment in many high-mountain temperate areas. This may lead to challenging decisions to be taken in nature reserves. Studies on the genetic structure of small plant populations have provided unexpected results about the lack of the correspondence between isolation 

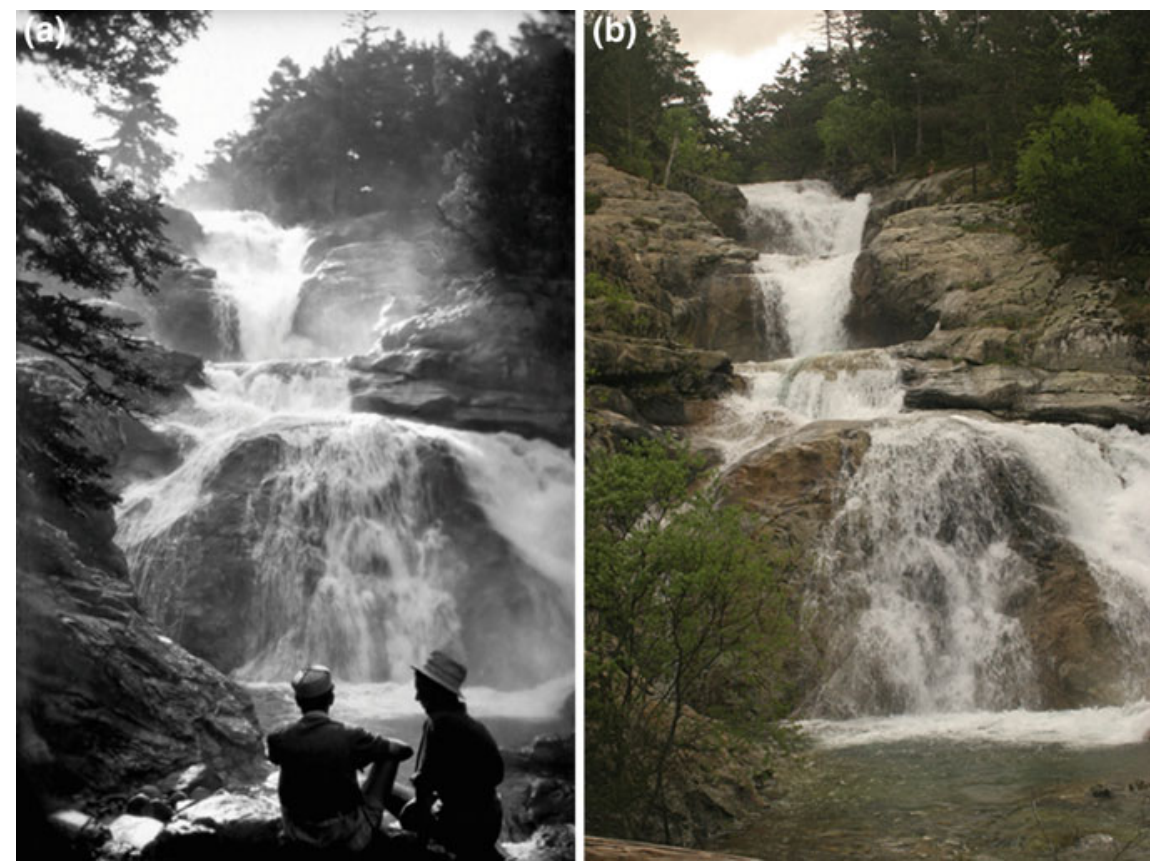

Fig. 1.8 Sant Esperit waterfall in the Aigüestortes i Estany de Sant Maurici National Park at 1950 (a) and 2010 (b). Scenic values are part of the mountain nature reserves. Historically, National Parks emerged in a period of national enthusiasm as a way to remark the singularities of a country's landscape. Although this view may have evolved, the symbolic elements of the landscape pervade from local to global scales, becoming icons of locations, values and natural processes. Photography: Ricard Novell archive (a) and Archive of the Aigüestortes i Estany de Sant Maurici National Park (b)

and genetic richness (Blanco-Pastor et al. 2013). Ad hoc studies may be helpful, before expending efforts in a wrong direction.

\subsubsection{Functional Versus Phylogenetic Conservation}

Criticism to estimated excessive effort on conservation actions towards preserving genetic variability and details in phylogeography issues advocates that conservation should aim to maintain functional diversity rather than to pay attention to taxonomic and phylogenetic details. This appears to be a false debate. It primarily depends on where one stops defining functional traits. The more detail we gain in functional attributes, the more we approach function to phylogenetic structures (Flynn et al. 2011). Trait convergence among scarcely related phylogenetic groups is a fact; however, convergence in some characters does not invalidate differences in others. So, in the end, any species is phylogenetically and ecologically unique. 
Preserving species preserves functions, with the added value that no judgments are required on which functions have to be prioritized. On the other hand, partial functional redundancy is a fact in nature. Probably simply by natural selection, essential functions have become more redundant than the ones less critical for the organization of ecosystem functioning regarding cycling of matter and energy flow.

\subsubsection{Size Matters}

It is unclear how much of the present distribution of species in high mountains is related to human influence. Treeline has been modified at least since about 3000 years ago in many European mountain valleys (Pèlachs et al. 2017). Fire was the tool to open the landscape (Tinner et al. 2005). The artificial maintenance of pasturing meadows at high altitude should have modified the species assemblage and favored some of them, according to the enhanced grazing and fertilization. It would be interesting to check whether a selection of species or morphotypes can be related to these increased pressures. Similarly, the human pressure on some trees may not have been genetically innocuous. Fir (Abies alba) is currently mostly restricted to north-facing slopes in the Pyrenean valleys. However, there is growing evidence that in the past, along the second half of the Holocene, it also extended through south-facing slopes over a larger area. Apparently, there are not climatic reasons for the observed change. Rather, there is growing palaeoecological evidence that humans have preferred to leave fir in the shaded areas and facilitate other species (e.g., pines (Pinus sylvestris, P. uncinata), or beech (Fagus sylvatica), among others) in the sunny slopes and plains. This practice may have lasted during centuries, perhaps actually introducing a shift towards these conditions in the Pyrenean fir metapopulation. Studies across the range of Abies alba indicate an intense human pressure on this tree in Southern Europe (Ruosch et al. 2016). In any case, with decreased forestry activity within and outside the nature reserves, current tree distribution in many mountains would be changing even without climate change. Many nature reserves may be too small to cope appropriately with these changes and forest mass conservation in general. Reserve size matters, at least concerning trees and large mammals, thus conservation policy outside natural reserves becomes a vital element for them. Natural reserves may provide space for pilot studies and observations to inform decisions over large mountain-areas regulation.

\subsubsection{Local Contribution to Global Ecological Services}

The task that mountain nature reserves may play in mitigating global change may appear as insignificant. Although carbon stock in soils and forests may be high per surface unit (Garcia-Pausas et al. 2017), the overall figure may become irrelevant 
when considering large areas. It may happen similarly with biodiversity preservation and any other of the components of current global change. Although ecological services to mitigate global change issues can be modest, the symbolism of mountain nature reserves may be valuable. Actions in mountain reserves may be mirrored in other areas covering larger extensions. It is not only a matter of education but also of symbolism. Mountains have had a symbolic appeal since ancient times, and they are still being so. Current conservation goals may emotionally link people to those traditional values [e.g., sacred lakes and forests (Brandt et al. 2013)].

\subsubsection{Conservation Beyond Conservation}

The conservation paradigm was built in a context in which a large part of the population had actual contact with natural environments through a rural life or recent memory of them. Even in those circumstances, the understanding and emotional connection to nature varied among cultures (Crowley 2013). Nowadays, more than half of the population of the planet has moved to the cities and a large part of the population in developed countries has only incidental contact with nature. Even among those that expend a lot of time outdoors, most are of urban origin, many are sports practitioners or specialized collectors with a limited understanding (interest) for how nature works as a whole. Conservation has had always a double appeal: emotional and rational. The hankering of preserving a past legacy is now challenged by global change but also by the loss of tight connections of humankind with nature.

The conservation paradigm has to face the new situation and accumulate as many as possible rational and emotional arguments. A leading token in that sense is the global stewardship humans are responsible for (Steffen et al. 2011). In this situation, new conservation values emerge; for instance, microbial conservation (Casamayor 2017) and biogeochemical ecosystem services (Garcia-Pausas et al. 2017). Saving big trees and bears is fine, but consciousness about our intervention in the dynamics of the whole planet system and the need to respond in an appropriate way to this challenge becomes a priority in the conservation paradigm. In contrast to trees and bears, microbes and biogeochemical pathways are scarcely apparent. Communication and visualization techniques in nature reserves have a great role to play in this issue, including the use of new technologies.

The more conservation suffers from social pressure, the more it is involved in the economic arena. This has pros and cons, but the tendency of a growing economics around conservation calls for more expert attention (Sala et al. 2013). The environment has been progressively accepted as an economic sector as pollution problems have been growing. Conservation has not fully been included yet in the same dynamics. It is still viewed in aesthetical terms rather than as a critical part of the socio-economic affairs. This flawy attitude is even shared by some professionals of environmental issues. They see conservation as a matter of preserving beautiful 
butterflies, instead of recognizing that the conservation paradigm provides the roots in which their activity is grounded.

The planet requires areas (land and sea) in which nature free dynamics can develop. These areas have to be sufficiently large to be more than an open zoo. On the other hand, conservation has to facilitate the contact of the citizens with the natural processes beyond TV shows. Therefore, rather than firm boundaries, a complex system of progressive zonation with different degrees of human presence and activities is desirable. The high-mountain landscape is naturally prompt to this situation. This is the reason why many nature reserves are located there. The harsher conditions with increasing altitude provide a natural softening of direct human incidence. However, preserving the highest lands cannot be at the expense of inhibition about lower areas. Nature conservation is crying for new developments in science and technology on natural and social fields according to the current challenging changing times.

Acknowledgements Although the authors are exclusively responsible for the content of this chapter, they have been largely inspired by the presentations and discussions in the international workshop on "The High Mountain in a Changing World: Challenges for conservation", which took place in Espot (4-6 November, 2015) as part of the activities for the 60th anniversary of the Aigüestortes i Estany de Sant Maurici National Park (Catalan Pyrenees, Spain). The authors acknowledge Jordi Vicente for the photograph selection and thank the authors for permission to include them in the chapter. The research projects CUL-PA (ref. 998/2013) and ARBALMONT (ref. 634S/2012) from the Spanish National Parks research program are also acknowledged.

\section{References}

Agnoletti M (2007) The degradation of traditional landscape in a mountain area of Tuscany during the 19th and 20th centuries: implications for biodiversity and sustainable management. For Ecol Manag 249:5-17

Anderson L (2012) Rocky Mountain hydroclimate: Holocene variability and the role of insolation, ENSO, and the North American Monsoon. Glob Planet Change 92-93:198-208

Bacardit M, Krachler M, Camarero L (2012) Whole-catchment inventories of trace metals in soils and sediments in mountain lake catchments in the Central Pyrenees: apportioning the anthropogenic and natural contributions. Geochim Cosmochim Acta 82:52-67

Barberan A, Henley J, Fierer N, Casamayor EO (2014) Structure, inter-annual recurrence, and global-scale connectivity of airborne microbial communities. Sci Total Environ 487:187-195

Bartrons M, Grimalt JO, de Mendoza G, Catalan J (2012) Pollutant dehalogenation capability may depend on the trophic evolutionary history of the organism: PBDEs in freshwater food webs. PLoS ONE 7:e41829

Beniston M (2006) Mountain weather and climate: a general overview and a focus on climatic change in the Alps. Hydrobiologia 562:3-16

Beniston M (2012) Impacts of climatic change on water and associated economic activities in the Swiss Alps. J Hydrol 412:291-296

Beniston M, Stoffel M (2014) Assessing the impacts of climatic change on mountain water resources. Sci Total Environ 493:1129-1137

Beniston M, Stoffel M (2016) Rain-on-snow events, floods and climate change in the Alps: events may increase with warming up to $4{ }^{\circ} \mathrm{C}$ and decrease thereafter. Sci Total Environ 571:228-236 
Beniston M, Stephenson DB, Christensen OB, Ferro CAT, Frei C, Goyette S, Halsnaes K, Holt T, Jylha K, Koffi B, Palutikof J, Schoell R, Semmler T, Woth K (2007) Future extreme events in European climate: an exploration of regional climate model projections. Clim Change 81:71-95

Berg MP, Kiers ET, Driessen G, van der Heijden M, Kooi BW, Kuenen F, Liefting M, Verhoef HA, Ellers J (2010) Adapt or disperse: understanding species persistence in a changing world. Glob Change Biol 16:587-598

Berrocal MC, Lopez MS, Gonzalez AU, Lopez-Saez JA (2014) Landscape construction and long-term economic practices: an example from the Spanish Mediterranean Uplands through rock art archaeology. J Archaeol Method Th 21:589-615

Birks HJB, Willis KJ (2008) Alpines, trees, and refugia in Europe. Plant Ecol Divers 1:147-160

Blanco-Pastor JL, Fernandez-Mazuecos M, Vargas P (2013) Past and future demographic dynamics of alpine species: limited genetic consequences despite dramatic range contraction in a plant from the Spanish Sierra Nevada. Mol Ecol 22:4177-4195

Blumthaler M, Ambach W (1990) Indication of increasing solar ultraviolet-B radiation flux in alpine regions. Science 248:206-208

Blumthaler M, Ambach W, Salzgeber M (1994) Effects of cloudiness on global and diffuse UV irradiance in a high-mountain area. Theor Appl Clim 50:23-30

Blumthaler M, Ambach W, Ellinger R (1997) Increase in solar UV radiation with altitude. J Photoch Photobio B 39:130-134

Bocquet A (1997) Archéologie et peuplement des Alpes françaises du Nord au néolithique et aux âges des métaux. L'Anthropologie 101:291-393

Bogdal C, Nikolic D, Luthi MP, Schenker U, Scheringer M, Hungerbuhler K (2010) Release of legacy pollutants from melting glaciers: model evidence and conceptual understanding. Environ Sci Technol 44:4063-4069

Boithias L, Acuna V, Vergonos L, Ziv G, Marce R, Sabater S (2014) Assessment of the water supply: demand ratios in a Mediterranean basin under different global change scenarios and mitigation alternatives. Sci Total Environ 470:567-577

Brandt JS, Wood EM, Pidgeon AM, Han LX, Fang ZD, Radeloff VC (2013) Sacred forests are keystone structures for forest bird conservation in southwest China's Himalayan Mountains. Biol Conserv 166:34-42

Burley JD, Theiss S, Bytnerowicz A, Gertler A, Schilling S, Zielinska B (2015) Surface ozone in the Lake Tahoe Basin. Atmos Environ 109:351-369

Camarero JJ (2017a) The multiple factors explaining decline in mountain forests: historical logging and warming-related drought stress cause silver fir dieback in the Aragón Pyrenees. In: Catalan J, Ninot JM, Aniz MM (eds) Challenges for high mountain conservation in a changing world. Springer, pp 131-154

Camarero JJ, Gazol A, Galván JD, Sangüesa-Barreda G, Gutiérrez E (2014) Disparate effects of global-change drivers on mountain conifer forests: warming-induced growth enhancement in young trees vs. $\mathrm{CO}_{2}$ fertilization in old trees from wet sites. Glob Change Biol 21:738-749

Camarero L (2017b) Atmospheric chemical loadings in the high mountain: current forcing and legacy pollution. In: Catalan J, Ninot JM, Aniz MM (eds) Challenges for high mountain conservation in a changing world. Springer, pp 325-341

Camarero L, Catalan J (2012) Atmospheric phosphorus deposition may cause lakes to revert from phosphorus limitation back to nitrogen limitation. Nat Commun 3:1118

Camarero L, Masque P, Devos W, Ani-Ragolta I, Catalan J, Moor HC, Pla S, Sanchez-Cabeza JA (1998) Historical variations in lead fluxes in the Pyrenees (northeast Spain) from a dated lake sediment core. Water Air Soil Pollut 105:439-449

Carey M, Baraer M, Mark BG, French A, Bury J, Young KR, McKenzie JM (2014) Toward hydro-social modeling: merging human variables and the social sciences with climate-glacier runoff models (Santa River, Peru). J Hydrol 518:60-70

Carrion JS (2002) Patterns and processes of Late Quaternary environmental change in a montane region of southwestern Europe. Quat Sci Rev 21:2047-2066 
Casamayor EO (2017) Towards a microbial conservation perspective in high-mountain lakes. In: Catalan J, Ninot JM, Aniz MM (eds) Challenges for high mountain conservation in a changing world. Springer, pp 157-180

Catalan J (2015) Tracking long-range atmospheric transport of trace metals, polycyclic aromatic hydrocarbons, and organohalogen compounds using lake sediments of mountain regions. In: Blais JM, Rosen MR, Smol JP (eds) Environmental contaminants, vol 18. Developments in paleoenvironmental research. Springer, Netherlands, pp 263-322

Catalan J, Vilalta R, Weitzman B, Ventura M, Comas E, Pigem C, Aranda R, Ballesteros E, Camarero L, García Serrano J, Pla S, Sáez A, Aiguabella P (1997) The hydraulic industry in the Pyrenees: evaluation, correction and prevention of the environmental impact at the Aigüestortes i estany de Sant Maurici National Park (In Catalan). La Caixa, Barcelona

Catalan J, Ventura M, Vives I, Grimalt JO (2004) The roles of food and water in the bioaccumulation of organochlorine compounds in high mountain lake fish. Environ Sci Technol 38:4269-4275

Catalan J, Bartrons M, Camarero L, Grimalt JO (2013) Mountain waters as witnesses of global pollution. In: Pechan P, Vries GEd (eds) Living with water: targeting quality in a dynamic world. Springer, New York, pp 31-67

Cocozza C, de Miguel M, Psidova E, Ditmarova L, Marino S, Maiuro L, Alvino A, Czajkowski T, Bolte A, Tognetti R (2016) Variation in ecophysiological traits and drought tolerance of beech (Fagus sylvatica L.) Seedlings from different populations. Front Plant Sci 7:886

Cristofanelli P, Bonasoni P (2009) Background ozone in the southern Europe and Mediterranean area: influence of the transport processes. Environ Pollut 157:1399-1406

Cristofanelli P, Bracci A, Sprenger M, Marinoni A, Bonafe U, Calzolari F, Duchi R, Laj P, Pichon JM, Roccato F, Venzac H, Vuillermoz E, Bonasoni P (2010) Tropospheric ozone variations at the Nepal climate observatory-pyramid (Himalayas, 5079 m a.s.l.) and influence of deep stratospheric intrusion events. Atmos Chem Phys 10:6537-6549

Crowley T (2013) Climbing mountains, hugging trees: a cross-cultural examination of love for nature. Emot Space Soc 6:44-53

Chapin FS III, Carpenter SR, Kofinas GP, Folke C, Abel N, Clark WC, Olsson P, Smith DMS, Walker B, Young OR, Berkes F, Biggs R, Grove JM, Naylor RL, Pinkerton E, Steffen W, Swanson FJ (2010) Ecosystem stewardship: sustainability strategies for a rapidly changing planet. Trends Ecol Evol 25:241-249

Chytry M, Maskell LC, Pino J, Pysek P, Vila M, Font X, Smart SM (2008) Habitat invasions by alien plants: a quantitative comparison among Mediterranean, subcontinental and oceanic regions of Europe. J Appl Ecol 45:448-458

Davidson DA, Wilkinson AC, Kimpe LE, Blais JM (2004) Persistent organic pollutants in air and vegetation from the Canadian Rocky Mountains. Environ Toxicol Chem 23:540-549

Dedieu JP, Lessard-Fontaine A, Ravazzani G, Cremonese E, Shalpykova G, Beniston M (2014) Shifting mountain snow patterns in a changing climate from remote sensing retrieval. Sci Total Environ 493:1267-1279

DeFries RS, Ellis EC, Chapin FS, Matson PA, Turner BL, Agrawal A, Crutzen PJ, Field C, Gleick P, Kareiva PM, Lambin E, Liverman D, Ostrom E, Sanchez PA, Syvitski J (2012) Planetary opportunities: a social contract for global change science to contribute to a sustainable future. Bioscience 62:603-606

Diaz HF, Bradley RS (1997) Temperature variations during the last century at high elevation sites. Clim Change 36:253-279

Dullinger S, Dirnbock T, Grabherr G (2004) Modelling climate change-driven treeline shifts: relative effects of temperature increase, dispersal and invasibility. J Ecol 92:241-252

Dullinger S, Dirnbock T, Kock R, Hochbichler E, Englisch T, Sauberer N, Grabherr G (2005) Interactions among tree-line conifers: differential effects of pine on spruce and larch. J Ecol 93:948-957

Dullinger S, Gattringer A, Thuiller W, Moser D, Zimmermann NE, Guisan A, Willner W, Plutzar C, Leitner M, Mang T, Caccianiga M, Dirnboeck T, Ertl S, Fischer A, Lenoir J, 
Svenning J-C, Psomas A, Schmatz DR, Silc U, Vittoz P, Huelber K (2012) Extinction debt of high-mountain plants under twenty-first-century climate change. Nat Clim Change 2:619-622

Elsen PR, Tingley MW (2015) Global mountain topography and the fate of montane species under climate change. Nat Clim Change 5:772-776

Elvira S, Gonzalez-Fernandez I, Alonso R, Sanz J, Bermejo-Bermejo V (2016) Ozone levels in the Spanish Sierra de Guadarrama mountain range are above the thresholds for plant protection: analysis at 2262, 1850, and $995 \mathrm{~m}$ a.s.1. Environ Monit Assess 188

Elliott JE, Levac J, Guigueno MF, Shaw DP, Wayland M, Morrissey CA, Muir DCG, Elliott KH (2012) Factors influencing legacy pollutant accumulation in alpine osprey: biology, topography, or melting glaciers? Environ Sci Technol 46:9681-9689

Engler R, Randin CF, Thuiller W, Dullinger S, Zimmermann NE, Araujo MB, Pearman PB, Le Lay G, Piedallu C, Albert CH, Choler P, Coldea G, De Lamo X, Dirnbock T, Gegout J-C, Gomez-Garcia D, Grytnes J-A, Heegaard E, Hoistad F, Nogues-Bravo D, Normand S, Puscas M, Sebastia M-T, Stanisci A, Theurillat J-P, Trivedi MR, Vittoz P, Guisan A (2011) 21st century climate change threatens mountain flora unequally across Europe. Glob Change Biol 17:2330-2341

Flo D, Hagvar S (2013) Aerial dispersal of invertebrates and mosses close to a receding alpine glacier in Southern Norway. Arct Antarct Alp Res 45:481-490

Flynn DFB, Mirotchnick N, Jain M, Palmer MI, Naeem S (2011) Functional and phylogenetic diversity as predictors of biodiversity-ecosystem-function relationships. Ecology 92:1573-1581

García M, Gómez D (2007) Flora del Pirineo Aragonés. Patrones espaciales de biodiversidad y su relevancia para la conservación. Pirineos 162:71-88

Garcia MB, Espadaler X, Olesen JM (2012) Extreme reproduction and survival of a true Cliffhanger: the endangered plant Borderea chouardii (Dioscoreaceae). PLoS ONE 7

Garcia-Pausas J, Romanyà J, Montané F, Rios AI, Taull M, Rovira P, Casals P (2017) Are soil carbon stocks in mountain grasslands compromised by land use changes? In: Catalan J, Ninot JM, Aniz MM (eds) Challenges for high mountain conservation in a changing world. Springer, pp 207-230

Garrard R, Kohler T, Price MF, Byers AC, Sherpa AR, Maharjan GR (2016) Land use and land cover change in Sagarmatha National Park, a world heritage site in the Himalayas of Eastern Nepal. Mt Res Dev 36:299-310

Gassiot Ballbè E, Mazzucco N, Clemente Conte I, Rodríguez Antón D, Obea Gómez L, Quesada Carrasco M, Díaz Bonilla S (2017) The beginning of high mountain occupations in the Pyrenees. Human settlements and mobility from 18,000 cal BC to 2000 cal BC. In: Catalan J, Ninot JM, Aniz MM (eds) Challenges for high mountain conservation in a changing world. Springer, pp 75-105

Gavin DG, Fitzpatrick MC, Gugger PF, Heath KD, Rodríguez-Sánchez F, Dobrowski SZ, Hampe A, Hu FS, Ashcroft MB, Bartlein PJ, Blois JL, Carstens BC, Davis EB, de Lafontaine G, Edwards ME, Fernandez M, Henne PD, Herring EM, Holden ZA, W-s Kong, Liu J, Magri D, Matzke NJ, McGlone MS, Saltré F, Stigall AL, Tsai Y-HE, Williams JW (2014) Climate refugia: joint inference from fossil records, species distribution models and phylogeography. New Phytol 204:37-54

Gobiet A, Kotlarski S, Beniston M, Heinrich G, Rajczak J, Stoffel M (2014) 21st century climate change in the European Alps-a review. Sci Total Environ 493:1138-1151

Gottfried M, Hantel M, Maurer C, Toechterle R, Pauli H, Grabherr G (2011) Coincidence of the alpine-nival ecotone with the summer snowline. Environ Res Lett 6:014013

Grimalt JO, van Drooge BL (2006) Polychlorinated biphenyls in mountain pine (Pinus uncinata) needles from Central Pyrenean high mountains (Catalonia, Spain). Ecotoxicol Environ Saf 63:61-67 
Grimalt JO, Fernandez P, Berdie L, Vilanova RM, Catalan J, Psenner R, Hofer R, Appleby PG, Rosseland BO, Lien L, Massabuau JC, Battarbee RW (2001) Selective trapping of organochlorine compounds in mountain lakes of temperate areas. Environ Sci Technol 35:2690-2697

Hampe A, Petit RJ (2005) Conserving biodiversity under climate change: the rear edge matters. Ecol Lett 8:461-467

Hanski I (2013) Extinction debt at different spatial scales. Anim Conserv 16:12-13

Hantel M, Hirtl-Wielke LM (2007) Sensitivity of Alpine snow cover to European temperature. Int J Climatol 27:1265-1275

Hegglin MI, Shepherd TG (2009) Large climate-induced changes in ultraviolet index and stratosphere-to-troposphere ozone flux. Nat Geosci 2:687-691

Herrero A, Zamora R (2014) Plant responses to extreme climatic events: a field test of resilience capacity at the southern range edge. PLoS ONE 9:e87842

Hickling R, Roy DB, Hill JK, Fox R, Thomas CD (2006) The distributions of a wide range of taxonomic groups are expanding polewards. Glob Change Biol 12:450-455

Hodar JA, Castro J, Zamora R (2003) Pine processionary caterpillar Thaumetopoea pityocampa as a new threat for relict Mediterranean Scots pine forests under climatic warming. Biol Conserv 110:123-129

Ignacio Lopez-Moreno J, Goyette S, Vicente-Serrano SM, Beniston M (2011) Effects of climate change on the intensity and frequency of heavy snowfall events in the Pyrenees. Clim Change 105:489-508

Jarque S, Quirós L, Grimalt JO, Gallego E, Catalan J, Lackner R, Piña B (2015) Background fish feminization effects in European remote sites. Sci Rep 5:11292

Komac B, Domenech M, Fanlo R (2014) Effects of grazing on plant species diversity and pasture quality in subalpine grasslands in the eastern Pyrenees (Andorra): implications for conservation. J Nat Conserv 22:247-255

Konchar KM, Staver B, Salick J, Chapagain A, Joshi L, Karki S, Lo S, Paudel A, Subedi P, Ghimire SK (2015) Adapting in the shadow of Annapurna: a climate tipping point. J Ethnobiol 35:449-471

Konvicka M, Maradova M, Benes J, Fric Z, Kepka P (2003) Uphill shifts in distribution of butterflies in the Czech Republic: effects of changing climate detected on a regional scale. Glob Ecol Biogeogr 12:403-410

Körner C (2007) The use of 'altitude' in ecological research. Trends Ecol Evol 22:569-574

Korner C, Paulsen J (2004) A world-wide study of high altitude treeline temperatures. J Biogeogr 31:713-732

Kuussaari M, Bommarco R, Heikkinen RK, Helm A, Krauss J, Lindborg R, Ockinger E, Partel M, Pino J, Roda F, Stefanescu C, Teder T, Zobel M, Steffan-Dewenter I (2009) Extinction debt: a challenge for biodiversity conservation. Trends Ecol Evol 24:564-571

Laiolo P, Obeso JR (2017) Life-history responses to the altitudinal gradient. In: Catalan J, Ninot JM, Aniz MM (eds) Challenges for high mountain conservation in a changing world. Springer, pp 253-283

Lapenis A, Shvidenko A, Shepaschenko D, Nilsson S, Aiyyer A (2005) Acclimation of Russian forests to recent changes in climate. Glob Change Biol 11:2090-2102

Lasanta-Martinez T, Vicente-Serrano SM, Cuadrat-Prats JM (2005) Mountain Mediterranean landscape evolution caused by the abandonment of traditional primary activities: a study of the Spanish Central Pyrenees. Appl Geogr 25:47-65

Li J, Wang ZF, Akimoto H, Gao C, Pochanart P, Wang XQ (2007) Modeling study of ozone seasonal cycle in lower troposphere over east Asia. J Geophys Res-Atmos 112

Lloret F (2017) Trade-offs in high mountain conservation. In: Catalan J, Ninot JM, Aniz MM (eds) Challenges for high mountain conservation in a changing world. Springer, pp 37-59

Lloret F, Siscart D, Dalmases C (2004) Canopy recovery after drought dieback in holm-oak Mediterranean forests of Catalonia (NE Spain). Glob Change Biol 10:2092-2099 
Margalef R (1976) Bases ecològiques per a una gestió de la natura. In: Folch R (ed) Natura, ús o abús? Editorial Barcino, Barcelona, pp 23-64

Margalida A (2017) Importance of long-term studies to conservation practice: the case of the bearded vulture in the Pyrenees. In: Catalan J, Ninot JM, Aniz MM (eds) Challenges for high mountain conservation in a changing world. Springer, pp 343-383

Martin Civantos JM (2014) Mountainous landscape domestication. Management of non-cultivated productive areas in Sierra Nevada (Granada-Almeria, Spain). Eur J Post-Class Archaeol 4:99103

McCullough IM, Davis FW, Dingman JR, Flint LE, Flint AL, Serra-Diaz JM, Syphard AD, Moritz MA, Hannah L, Franklin J (2016) High and dry: high elevations disproportionately exposed to regional climate change in Mediterranean-climate landscapes. Landsc Ecol 31:1063-1075

Miehe G, Miehe S, Bohner J, Kaiser K, Hensen I, Madsen D, Liu JQ, Opgenoorth L (2014) How old is the human footprint in the world's largest alpine ecosystem? A review of multiproxy records from the Tibetan Plateau from the ecologists' viewpoint. Quat Sci Rev 86:190-209

Miró A, Ventura M (2013) Historical use, fishing management and lake characteristics explain the presence of non-native trout in Pyrenean lakes: implications for conservation. Biol Conserv $167: 17-24$

Mitchell D, Paniker L, Lin K, Fernandez A (2015) Interspecific variation in the repair of UV damaged DNA in the genus Xiphophorus as a factor in the decline of the Rio Grande Platyfish. Photochem Photobiol 91:486-492

Moran-Tejeda E, Ignacio Lopez-Moreno J, Beniston M (2013) The changing roles of temperature and precipitation on snowpack variability in Switzerland as a function of altitude. Geophys Res Lett 40:2131-2136

Moran-Tejeda E, Lorenzo-Lacruz J, Ignacio Lopez-Moreno J, Rahman K, Beniston M (2014) Streamflow timing of mountain rivers in Spain: recent changes and future projections. J Hydrol 517:1114-1127

Morán-Tejeda E, López-Moreno JI, Sanmiguel-Vallelado A (2017) Changes in climate, snow and water resources in the Spanish Pyrenees: observations and projections in a warming climate. In: Catalan J, Ninot JM, Aniz MM (eds) Challenges for high mountain conservation in a changing world. Springer, pp 305-323

Muir DCG, Howard PH (2006) Are there other persistent organic pollutants? A challenge for environmental chemists. Environ Sci Technol 40:7157-7166

Nogues-Bravo D, Araujo MB, Errea MP, Martinez-Rica JP (2007) Exposure of global mountain systems to climate warming during the 21st century. Glob Environ Change-Hum Policy Dimens 17:420-428

Noyes PD, McElwee MK, Miller HD, Clark BW, Van Tiem LA, Walcott KC, Erwin KN, Levin ED (2009) The toxicology of climate change: environmental contaminants in a warming world. Environ Int 35:971-986

Nyaupane GP, Lew AA, Tatsugawa K (2014) Perceptions of trekking tourism and social and environmental change in Nepal's Himalayas. Tour Geogr 16:415-437

Oian H (2013) Wilderness tourism and the moralities of commitment: hunting and angling as modes of engaging with the natures and animals of rural landscapes in Norway. J Rural Stud 32:177-185

Ooi N, Laing J, Mair J (2015) Sociocultural change facing ranchers in the Rocky Mountain West as a result of mountain resort tourism and amenity migration. J Rural Stud 41:59-71

Palazón S (2017) The importance of reintroducing large carnivores: the brown bear in the Pyrenees. In: Catalan J, Ninot JM, Aniz MM (eds) Challenges for high mountain conservation in a changing world. Springer, pp 231-249

Pauchard A, Kueffer C, Dietz H, Daehler CC, Alexander J, Edwards PJ, Ramon Arevalo J, Cavieres LA, Guisan A, Haider S, Jakobs G, McDougall K, Millar CI, Naylor BJ, Parks CG, Rew LJ, Seipel T (2009) Ain't no mountain high enough: plant invasions reaching new elevations. Front Ecol Environ 7:479-486 
Pearson RG (2016) Reasons to conserve nature. Trends Ecol Evol 31:366-371

Pèlachs A, Nadal J, Manuel Soriano J, Molina D, Cunill R (2009) Changes in Pyrenean woodlands as a result of the intensity of human exploitation: 2,000 years of metallurgy in Vallferrera, northeast Iberian Peninsula. Veg Hist Archaeobot 18:403-416

Pèlachs A, Pérez-Obiol R, Soriano JM, Cunill R, Bal M-C, García-Codron JC (2017) The role of environmental geohistory in high mountain landscape conservation. In: Catalan J, Ninot JM, Aniz MM (eds) Challenges for high mountain conservation in a changing world. Springer, pp 107-129

Penuelas J, Poulter B, Sardans J, Ciais P, van der Velde M, Bopp L, Boucher O, Godderis Y, Hinsinger P, Llusia J, Nardin E, Vicca S, Obersteiner M, Janssens IA (2013a) Human-induced nitrogen-phosphorus imbalances alter natural and managed ecosystems across the globe. Nat Commun 4

Penuelas J, Sardans J, Estiarte M, Ogaya R, Carnicer J, Coll M, Barbeta A, Rivas-Ubach A, Llusia J, Garbulsky M, Filella I, Jump AS (2013b) Evidence of current impact of climate change on life: a walk from genes to the biosphere. Glob Change Biol 19:2303-2338

Petit RJ, El Mousadik A, Pons O (1998) Identifying populations for conservation on the basis of genetic markers. Conserv Biol 12:844-855

Pond GJ, Passmore ME, Borsuk FA, Reynolds L, Rose CJ (2008) Downstream effects of mountaintop coal mining: comparing biological conditions using family- and genus-level macroinvertebrate bioassessment tools. J North Am Benthol Soc 27:717-737

Psenner R, Catalan J (1994) Chemical composition of lakes in crystalline basins: a combination of atmospheric deposition, geologic background, biological activity and human action. In: Margalef R (ed) Limnology now: a paradigm of planetary problems. Elsevier Science B.V., pp 255-314

Quiros L, Jarque S, Lackner R, Fernandez P, Grimalt JO, Pina B (2007) Physiological response to persistent organic pollutants in fish from mountain lakes: analysis of Cyp1A gene expression in natural populations of Salmo trutta. Environ Sci Technol 41:5154-5160

Rabasa SG, Granda E, Benavides R, Kunstler G, Espelta JM, Ogaya R, Penuelas J, Scherer-Lorenzen M, Gil W, Grodzki W, Ambrozy S, Bergh J, Hodar JA, Zamora R, Valladares F (2013) Disparity in elevational shifts of European trees in response to recent climate warming. Glob Change Biol 19:2490-2499

Radkau J (2008) Nature and power. A global history of the environment. Cambridge University Press, Cambridge

Rangwala I, Barsugli J, Cozzetto K, Neff J, Prairie J (2012) Mid-21st century projections in temperature extremes in the southern Colorado Rocky Mountains from regional climate models. Clim Dyn 39:1823-1840

Reich PB, Sendall KM, Stefanski A, Wei XR, Rich RL, Montgomery RA (2016) Boreal and temperate trees show strong acclimation of respiration to warming. Nature 531:633-636

Rixen C, Wipf S (2017) Non-equilibrium in alpine plant assemblages: current shifts in Europe's summit floras). In: Catalan J, Ninot JM, Aniz MM (eds) Challenges for high mountain conservation in a changing world. Springer, pp 285-303

Rosenzweig ML (1995) Species diversity in space and time. Cambridge University Press, Cambridge

Rotherham ID (2013) Emerging concepts and case studies of eco-cultural tourism. Cult Tour 74-89

Ruosch M, Spahni R, Joos F, Henne PD, van der Knaap WO, Tinner W (2016) Past and future evolution of Abies alba forests in Europe - comparison of a dynamic vegetation model with palaeo data and observations. Glob Change Biol 22:727-740

Sala E, Costello C, Dougherty D, Heal G, Kelleher K, Murray JH, Rosenberg AA, Sumaila R (2013) A general business model for marine reserves. PLoS ONE 8:e58799

Schirpke U, Holzler S, Leitinger G, Bacher M, Tappeiner U, Tasser E (2013) Can we model the scenic beauty of an alpine landscape? Sustainability 5:1080-1094 
Schmid P, Kohler M, Gujer E, Zennegg M, Lanfranchi M (2007) Persistent organic pollutants, brominated flame retardants and synthetic musks in fish from remote alpine lakes in Switzerland. Chemosphere 67:S16-S21

Schmid P, Bogdal C, Bluthgen N, Anselmetti FS, Zwyssig A, Hungerbuhler K (2011) The missing piece: sediment records in remote mountain lakes confirm glaciers being secondary sources of persistent organic pollutants. Environ Sci Technol 45:203-208

Schmidt R, Koinig KA, Thompson R, Kamenik C (2002) A multi proxy core study of the last 7000 years of climate and alpine land-use impacts on an Austrian mountain lake (Unterer Landschitzsee, Niedere Tauern). Palaeogeogr Palaeoclimatol Palaeoecol 187:101-120

Schmitt T (2017) Molecular biogeography of the high mountain systems of Europe: an overview. In: Catalan J, Ninot JM, Aniz MM (eds) Challenges for high mountain conservation in a changing world. Springer, pp 63-74

Segarra-Moragues JG, Catalan P (2010) The fewer and the better: prioritization of populations for conservation under limited resources, a genetic study with Borderea pyrenaica (Dioscoreaceae) in the Pyrenean National Park. Genetica 138:363-376

Seppa H, Nyman M, Korhola A, Weckstrom J (2002) Changes of treelines and alpine vegetation in relation to post-glacial climate dynamics in northern Fennoscandia based on pollen and chironomid records. J Quat Sci 17:287-301

Shestakova TA, Gutiérrez E, Kirdyanov AV, Camarero JJ, Génova M, Knorre AA, Linares JC, Resco de Dios V, Sánchez-Salguero R, Voltas J (2016) Forests synchronize their growth in contrasting Eurasian regions in response to climate warming. Proc Natl Acad Sci USA 113:662-667

Shunthirasingham C, Wania F, MacLeod M, Lei YD, Quinn CL, Zhang XM, Scheringer M, Wegmann F, Hungerbuhler K, Ivemeyer S, Heil F, Klocke P, Pacepavicius G, Alaee M (2013) Mountain cold-trapping increases transfer of persistent organic pollutants from atmosphere to cows' milk. Environ Sci Technol 47:9175-9181

Steffen W, Persson A, Deutsch L, Zalasiewicz J, Williams M, Richardson K, Crumley C, Crutzen P, Folke C, Gordon L, Molina M, Ramanathan V, Rockstrom J, Scheffer M, Schellnhuber HJ, Svedin U (2011) The anthropocene: from global change to planetary stewardship. Ambio 40:739-761

Steffen W, Richardson K, Rockström J, Cornell SE, Fetzer I, Bennett EM, Biggs R, Carpenter SR, de Vries W, de Wit CA, Folke C, Gerten D, Heinke J, Mace GM, Persson LM, Ramanathan V, Reyers B, Sörlin S (2015) Planetary boundaries: guiding human development on a changing planet. Science 347

Stevens CJ, Lind EM, Hautier Y, Harpole WS, Borer ET, Hobbie S, Seabloom EW, Ladwig L, Bakker JD, Chu CJ, Collins S, Davies KF, Firn J, Hillebrand H, La Pierre KJ, MacDougall A, Melbourne B, McCulley RL, Morgan J, Orrock JL, Prober SM, Risch AC, Schuetz M, Wragg PD (2015) Anthropogenic nitrogen deposition predicts local grassland primary production worldwide. Ecology 96:1459-1465

Theurillat JP, Guisan A (2001) Potential impact of climate change on vegetation in the European Alps: a review. Clim Change 50:77-109

Thomas CD (2010) Climate, climate change and range boundaries. Divers Distrib 16:488-495

Tinner W, Conedera M, Ammann B, Lotter AF (2005) Fire ecology north and south of the Alps since the last ice age. Holocene 15:1214-1226

Tylianakis JM, Didham RK, Bascompte J, Wardle DA (2008) Global change and species interactions in terrestrial ecosystems. Ecol Lett 11:1351-1363

Uglietti C, Gabrielli P, Cooke CA, Vallelonga P, Thompson LG (2015) Widespread pollution of the South American atmosphere predates the industrial revolution by 240 y. Proc Natl Acad Sci USA 112:2349-2354

Uhlmann B, Goyette S, Beniston M (2009) Sensitivity analysis of snow patterns in Swiss ski resorts to shifts in temperature, precipitation and humidity under conditions of climate change. Int J Climatol 29:1048-1055 
Ventura M, Tiberti R, Buchaca T, Buñay D, Sabás I, Miró A (2017) Why should we preserve fishless high-mountain lakes? In: Catalan J, Ninot JM, Aniz MM (eds) Challenges for high mountain conservation in a changing world. Springer, pp 181-205

Wake DB, Vredenburg VT (2008) Are we in the midst of the sixth mass extinction? A view from the world of amphibians. Proc Natl Acad Sci USA 105:11466-11473

Walsh K (2014) The archaeology of Mediterranean landscapes. Cambridge University Press, Cambridge

Wania F, Westgate JN (2008) On the mechanism of mountain cold-trapping of organic chemicals. Environ Sci Technol 42:9092-9098

Weber J, Halsall CJ, Muir D, Teixeira C, Small J, Solomon K, Hermanson M, Hung H, Bidleman T (2010) Endosulfan, a global pesticide: a review of its fate in the environment and occurrence in the Arctic. Sci Total Environ 408:2966-2984

WGMS (2015) Global glacier change bulletin no. 1 (2012-2013). Publication based on database version: doi:10.5904/wgms-fog-2015-11. Zurich, Switzerland

Wickham J, Wood PB, Nicholson MC, Jenkins W, Druckenbrod D, Suter GW, Strager MP, Mazzarella C, Galloway W, Amos J (2013) The overlooked terrestrial impacts of mountaintop mining. Bioscience 63:335-348

Wiegand T, Camarero JJ, Ruger N, Gutierrez E (2006) Abrupt population changes in treeline ecotones along smooth gradients. J Ecol 94:880-892

Wilson RJ, Gutierrez D, Gutierrez J, Martinez D, Agudo R, Monserrat VJ (2005) Changes to the elevational limits and extent of species ranges associated with climate change. Ecol Lett 8:1138-1146

Wittig VE, Ainsworth EA, Naidu SL, Karnosky DF, Long SP (2009) Quantifying the impact of current and future tropospheric ozone on tree biomass, growth, physiology and biochemistry: a quantitative meta-analysis. Glob Change Biol 15:396-424

Xu JC, Grumbine RE, Shrestha A, Eriksson M, Yang XF, Wang Y, Wilkes A (2009) The melting Himalayas: cascading effects of climate change on water, biodiversity, and livelihoods. Conserv Biol 23:520-530

Zamora R, Pérez-Luque AJ, Bonet FJ (2017) Monitoring global change in high mountains. In: Catalan J, Ninot JM, Aniz MM (eds) Challenges for high mountain conservation in a changing world. Springer, pp 385-413

Zemp M, Frey H, Gärtner-Roer I, Nussbaumer SU, Hoelzle M, Paul F, Haeberli W, Denzinger F, Ahlstrøm AP, Anderson B, Bajracharya S, Baroni C, Braun LN, Cáceres BE, Casassa G, Cobos G, Dávila LR, Delgado Granados H, Demuth MN, Espizua L, Fischer A, Fujita K, Gadek B, Ghazanfar A, Hagen JO, Holmlund P, Karimi N, Li Z, Pelto M, Pitte P, Popovnin VV, Portocarrero CA, Prinz R, Sangewar CV, Severskiy I, Sigurðsson O, Soruco A, Usubaliev R, Vincent C (2015) Historically unprecedented global glacier decline in the early 21st century. J Glaciol 61:745-762

Open Access This chapter is licensed under the terms of the Creative Commons Attribution 4.0 International License (http://creativecommons.org/licenses/by/4.0/), which permits use, sharing, adaptation, distribution and reproduction in any medium or format, as long as you give appropriate credit to the original author(s) and the source, provide a link to the Creative Commons license and indicate if changes were made.

The images or other third party material in this chapter are included in the chapter's Creative Commons license, unless indicated otherwise in a credit line to the material. If material is not included in the chapter's Creative Commons license and your intended use is not permitted by statutory regulation or exceeds the permitted use, you will need to obtain permission directly from the copyright holder.

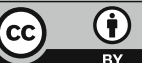

